九州大学学術情報リポジトリ

Kyushu University Institutional Repository

Studies on six species of the genera Paranthrene Hübner and Conopia Hübner from Japan (Lepidoptera, Aegeri idae)

Yano, Koji

Entomological Laboratory, Department of Agriculture, Kyushu University

https://doi.org/10.5109/22685

出版情報: 九州大学大学院農学研究院紀要. 11 (3)，pp. 209-236，1961-11. Kyushu University バージョン：

権利関係 : 


\begin{abstract}
Journal of the Faculty of Agriculture, Kyūshū University, Vol. 11, No. 3 November 30, 1961
\end{abstract}

\title{
Studies on six species of the genera Paranthrene Hübner and Conopia Hübner from Japan \\ (Lepidoptera, Aegeriidae) $^{1}$
}

KôJI YANO

On the Japanese species of the family Aegeriidae there remain some taxonomic problems to investigate still more. Furthermore, we have rather few informations regarding the earlier stages of them at the present time. The present paper deals with six species of the family which are belonging to two genera, Paranthrene. Hubner and Conopia Hübner, on their taxonomics and life histories. Three synonyms are discussed herewith. The life histories of $P$. yezonica and C. tenuis are mentioned for the first time in the present paper. The descriptions on the earlier stages of the other four species, which were briefly described before, are given also in the present paper. From the economical point of view these six species except for $P$. yezonica and $P$. pernix have fairly or considerably important relationship to various trees containing truit trees. As to $P$. yezonica, however, we should watch carefully its possible invasion to the vineyard in future by the reason which will be mentioned below. The nomenclature used for the setae of the larva, except for the labrum, is that of Hinton (1946). On the setae of the labrum the author adopted the nomenclature of Heinrich (1916).

Before going further, the author wishes to express his hearty thanks to Prof. K. Yasumatsu and Prof. Y. Hirashima for their kind guidance and constant encouragement in the course of the present study. His hearty thanks are also due to Prof. T. Uchida and Prof. C. Watanabe who gave to the author the opportunity to examine the collection of Hokkaido University, to Prof. S. Isski, of the University of Osaka Prefecture, and Mr. J. D. Bradley, of the British Museum (Nat. Hist.), for their kindness in offering valuable advice and literature, and to Mr. T. Yasuda, Mr. Y. Matuda, Mr. T. Saigusa and other gentlemen for their help in materials and other ways.

\footnotetext{
1 Contribution Ser. 2, No. 85, Entomological Laboratory, Kyushu University.
} 


\section{Genus Paranthrene Hübner, 1827}

Up to the present, six species of the genus Paranthrene Hübner have been recorded from Japan. Among them, P. hirayamai Matsumura is treated as a synonym of $P$. pernix (Leech) in the present paper. $P$. bicincta (Walker) may occur only in China on account of the reason which will be mentioned hereafter. Therefore there occur four species in Japan, three of which are dealt in the present paper.

General characters to the following species.

Antennae slightly or moderately serrate, strongly ciliate beneath at about basal three-fourths, and cilia becoming gradually shorter towards distal end in the male. Female antennae simple with minute cilia beneath and each joint beneath ringed with scales except towards tips. Antennae of both sexes smoothly scaled above and ending in a small hair tuft. Labial palpi erect, terminal joint short. Proboscis well developed. Hindwings with vein 3 from the angle of cell or just before the angle, $1 \mathrm{c}$ and discocellulars moderately or heavily scaled. Fore femora and tibiae with long hairs posteriorly; mid and hind femora posteriorly with hairs; hind tibiae roughly scaled above; tarsi of all legs smooth. Abdomen with prominent anal tuft, paired tufts of hairs or fan-shaped in the male, simple and flat in the female. Male genitalia: long, erect socii clothed with long scale-like hairs; elongate ventral plate supporting tuba analis; gnathos developed, heavily sclerotized; anellus rather weakly sclerotized laterally, forming two arms of juxta; costal area of valva clothed with palmate spines, ventral area without spines, ventral margin with long hairs, sacculus ridge with stout undivided spines; aedoeagus bulbous at the base and with or without a downward-pointed hook just below the apex. Female genitalia: corpus bursae finely transversely wrinkled or not so, without signum.

\section{Mature larva.}

Body cylindrical. Head broader than long, retracted within prothorax; vertical triangle very deep; frontal suture sometimes indistinct and joining vertical triangle or well before the triangle; fronto-clypeal region (excluding anteclypeus) longer than wide. Labrum with a slight median incision at the anterior margin. Mandible with four or five teeth. Ocelli six on each side, in normal Aegeriid arrangement, viz. ocelli V and VI remote from the others, except P. pernix; ocelli I, II and III forming a right or obtuse angle at the ocellus II. Meso- and metathorax with small reddish brown spot just ventrad from seta L3. Spiracles on 8th abdominal segment well dorsad from the level of the others. Ventral prolegs with two transverse rows of uniordinal crochets; anal prolegs with one transverse row of uniordinal crochets. Crochets long, sometimes bulbous at the base in anal prolegs. Crochets 
of ventral prolegs having a tendency of decreasing in number towards posterior segments. Body invested with minute spines, round or somewhat pointed except sclerotized area and decreasing in density ventrally and towards caudal end of body. Colour: head brown, with paler area adjacent to frontal suture and vertical triangle, darkened at marginal area. Body yellowish white; prothoracic shield pale yellow or yellowish brown with a dark oblique stripe; anal plate yellowish brown scattered with brown spots; pinacula somewhat distinct. Chaetotaxy: head with seta P2 very minute; vertical setae with puncture $\mathrm{Va}$ forming an obtuse angle at $\mathrm{V} 2$; $\mathrm{V} 2$ mesad from a line joining $\mathrm{V} 1$ and V3; extremely minute seta or puncture between ocelli III and IV; Oc laterad from a line joining $\mathrm{O} 2$ and SO3. Puncture Fa well below the level of $\mathrm{Fl}$; $\mathrm{AF} 2$ below the apex of fronto-clypeal region; AF1 and P2 extremely minute; P1 below the level of AFa. Labrum with two labral punctures; setae of lateral group remote from a median group, arranged in a line along the lateral margin, equidistant or nearly so; setae of a median group forming a triangle, nearly equidistant; M2 postero-laterad from M1. Epipharynx with two or four punctures, without an epipharyngeal shield. Epipharyngeal setae triangularly grouped near anterior lateral margin of epipharynx and approximate to each other; median seta directly behind anterior seta; slender and pointed. Prothorax with usually three punctures of microscopic XD group; XDb sometimes indistinct; setae of SV group bisetose. Abdominal segments with SD2 extremely minutes as microscopic seta; SV group of 2 nd -7 th abdominal segments trisetose; D1 slightly dorsad from D2 on 1st-4th abdominal segments, on the same level on 5th abdominal segment and slightly ventrad on 6 th-8th abdominal segments.

Biologically this genus is divided into two groups. In the first group the larva transforms to the pupal stage without making a cocoon, while in the second the larva constructs a cocoon before pupation.

Pupa.

Body elongate or short. Cephalic end of body nearly rounded but front with a prominent cephalic projection forming a curved ridge which is very broad or moderate, and sometimes with a rather broad median ridge and depressions at the sides on dorsal face. The dorsal face of front with two setae. Vertex narrow. Epicranial suture well indicated. Clypeus with two pairs of setae; clypeo-labral suture inconspicuous but labrum and pilifers elevated and rugged; maxillary palpi and labial palpi well indicated, the latter sinuate at lateral margin and united at basal part; maxillae and antennae long, the former well extending beyond tips of prothoracic legs but not reaching tips of antennae; the latter extending to nearly half the distance 
between tips of prothoracic legs and forewings; prothoracic legs well defined, coxae with an inconspicuous median oblique suture; mesothoracic legs not reaching tips of forewings; metathoracic legs fairly long exposed. Pro- and mesothorax with a carinate median ridge which is weak at caudal half of the latter. Prothorax with slit-like spiracles at caudo-lateral angles. Mesothorax with deep alar furrows on the sides, and with a seta in each furrow; metathorax with a seta at cephalic extremity on each side. Forewings elongate somewhat pointed at tips. Hindwings not reaching tips of forewings. First abdominal segment without a spine but with two setae on dorsum or sides. Cephalic margins of 2nd-8th abdominal segments with a transverse row of spines on dorsum; 9th abdominal segment with either a prominent transverse row of spines on dorsum or a few spines on each side, rarely without spine. Caudal margins of 2 nd- 7 th abdominal segments in the male, 2nd-6th abdominal segments in the female, with a transverse row of minute spines on dorsum. Abdominal segment 10 with broad spines which are encircling an anal opening; usually each of the spines has a short seta. Second-eighth abdominal segments with spiracles on the sides, those of 8 th abdominal segment fairly dorsad from the level of the others. Ventral suture between 8th and 9 th abdominal segments usually distinct in the male. Genital opening slit-like in both sexes, the sides of it somewhat elevated in the male. Anal opening slit-like or Y-shaped.

\section{Paranthrene regale (Butler, 1878)}

Sciapteron regale Butler, Ill. Lep. Het. Brit. Mus. 2: 60, pl. 40, fig. 3, 1878; Leech, Proc. Zool. Soc. Lond. 1888: 591, 1888; Matsumura, Cat. Ins. Jap. 1: 187, 1905; Matsumura, Thous. Ins. Jap. Suppl. 3: 88, pl. 36, fig. 268, 1911.

Paranthrene regale Bartel, in Seitz. Macrolep. (Pal.) 2: 380, pl. 51, flg. b, 1912; Matsumura, 6000 III. Ins. Jap. 1: 1016, no. 1865, 1931; Inoue, Check List Lep. Jap. 1: 45, 1954; Inoue, Icon. Het. Jap. Col. Nat. 1: 154, pl. 27, fig. 802, 1957; Shirôzu, Icon. Ins. Jap. Col. Nat. Ed. 1: 229, pl. 164, figs. 10a, b, 1959.

Paranthrene regalis Hampson, Novit. Zool. 26: 102, 1919; Dalla Torre et Strand, Lep. Cat. 31: 162, 1925; Matsumura, Ins. Mats. 6 (1): 11, 1931; Kawada, Icon. Ins. Jap. (rev. ed.) : 558, fig. 1536, 1950.

Vitacea regale Engelhardt, Bull. U. S. Nat. Mus. 190: 151, 1946.

Male. (P1. 11, fig. 1; P1. 14, figs. 1, 2)

Antennae shiny purplish black above, brown beneath. Vertex with long orange hairs; from greyish white. Occipital fringe orange. Labial palpi broad, brushy at first and second joints; black at first joint and outer sides of second joint, second joint in front and terminal one deep yellow. Thorax black, anterior margin and the sides of prothorax orange, patagia dark brown slightly mixed with orange scales, tegulae sometimes edged very narrowly with orange; a spot at 
the base of forewings orange; meso- and metathorax each with two orange patches on posterior dorsum; mesothorax sometimes with minute white hairs. Forewings reddish brown; costa, veins and outer margin dark brown. Hindwings transparent, sometimes tinged with pale brown; veins and margins dark brown; discocellulars mixed with reddish brown. Fringes of both wings greyish brown. Veins 3 and 4 of hindwings from the angle of cell. Underside of forewings reddish brown, costa yellowish, veins dark brown; hindwings with veins and margins reddish brown. Legs dark brown; trochanters of all legs yellowish white; fore femora and tibiae with long hairs posteriorly; fore tarsi pale yellow ventrally; mid and hind femora posteriorly with white hairs and the latter posteriorly edged with yellowish white; mid tibiae mixed with yellow; hind tibiae posteriorly yellow; mid and hind tarsi yellowish white. Abdomen black; 4th-7th abdominal segments banded posteriorly with orange above and sides; the bands of 4 th and 6 th abdominal segments somewhat broad and the former continuing beneath. Anal tuft with paired tufts of hairs, black, slightly mixed with orange. Genitalia: ventral plate at median part sclerotized basally and narrowing towards the base; gnathos with three projections; vinculum with slender saccus; valva elongate-ovate, clothed with inwardly directed palmate spines only on the costal half, apex and ventral margin except sacculus with long inwardly directed hairs, sacculus ridge with stout spines; aedoeagus bulbous at the base and with a downwardpointed hook just below the apex.

Female. (P1. 11, fig. 2; P1. 16, fig. 1)

Fourth-sixth abdominal segments posteriorly banded with orange above and sides; the band of 4 th abdominal segment very broad and continuing beneath and that of 5 th abdominal segment narrow; 3rd abdominal segment rarely ringed with orange very narrowly; the bands of 5 th and 6 th abdominal segments rarely continuing beneath. Anal tuft flat, black and slightly mixed with orange. Genitalia: corpus bursae short-ovate without signum, finely transversely wrinkled, reticulate at apical one-fourth or one-third.

Length of forewing: Male $13-16 \mathrm{~mm}$., female $14-18 \mathrm{~mm}$.

Specimens examined: 2 令 \& 2우, Kawachi Nagano, Osaka Pref.,

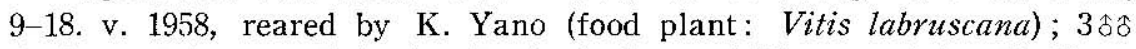
\& 6뭉, Fukuoka, Fukuoka Pref., 3-16. v. 1958, reared by K. Yano (food plant: V. thunbergii). Besides, 16 specimens (7今^ \& 9우) were examined.

Habitat: Japan (Hokkaido, Honshu, Shikoku and Kyushu), Korea and Manchuria.

Engelhardt (1946) established a new genus Vitacea, which is closely allied to Paranthrene, and mentions that this species may belong to his genus together with the six American species and forms. However, 
this species is separable from Vitacea in having a downward hook at the apex of the aedoeagus and two long hair tufts at the caudal end of the abdomen. Moreover, the species together with the following two ones has a peculiar genitalic character as mentioned already.

Mature larva. (Pl. 17, figs. 1, 6; Pl. 18, figs. 1, 2, 9, 13, 17, 21; Pl. 19, figs. $1,6,7,8,12,14$ )

Body cylindrical, tapering from 7th abdominal segment to caudal end of body. Head much broader than long; frontal suture joining a median adfrontal suture at a point two-thirds from vertical triangle; fronto-clypeal region (excluding anteclypeus) about two-thirds as broad as long. Ocelli I, II and III forming a triangle with an obtuse angle at the ocellus II. Mandible with four teeth, outer three of which are stout and prominent, the fourth much broader than long and somewhat pointed, inner part with a few slight incisions. Spiracles on prothorax and 8th abdominal segment twice the size of those on 1st-7th abdominal segments. Spiracles on prothorax elliptical. First and 2nd abdominal segments each with a sclerotized area which has no seta at caudal margin on meson. Crochets of ventral prolegs $15 \pm$ in a row, stout; those of anal prolegs $9 \pm$. Body invested with minute spines as shown in P1. 19, fig. 14. Colour: head brown, leaving a pale yellow area along the frontal suture, outer margin of the area with irregular projections; all margins of vertex, anterior margin of adfrontal area and the base of seta P1 dark brown; anteclypeus yellowish white, semitransparent; frontal suture white. Labrum reddish brown at the base of all setae. Body yellowish white; prothoracic shield pale yellowish brown with an oblique brown stripe; thoracic legs brown; pinacula yellowish white; anal plate yellowish brown scattered with pale brown spots. Crochets brown, dark brown at the extremities. Chaetotaxy: head with puncture AFa closely approximate to $\mathrm{AF} 2 ; \mathrm{Pb}$ equidistant from V1 and P2 or sometimes slightly nearer to the latter; A.2 laterad from a line joining $\mathrm{A} 1$ and $\mathrm{Aa}$ and sometimes varies in position, usually equidistant from them or slightly nearer to $\mathrm{Aa}$; seta $\mathrm{C} 2$ longer than $\mathrm{F} 1$; puncture $\mathrm{Oc}$ separated from $\mathrm{O} 2$; $\mathrm{O} 1$ closely approximate to ocellus III. Labrum with seta La2 slightly nearer to La1; seta M2 slightly behind of the level of La1. Epipharynx with four punctures. Prothorax with seta SD2 which varies in position, usually postero-dorsad from SD1, rarely ventro-cephalad from SD1 or nearer to XD2; XDb sometimes indistinct; L3 somewhat remote from L1 and L2. Setae of SV group with common pinacula on 1st-7th abdominal segments. Setae of body pale yellowish brown to pale reddish brown.

Length: $28-32 \mathrm{~mm}$. Head width: $4 \mathrm{~mm}$.

Pupa. (P1. 20, figs. 1, 2, 3, 4)

Reddish brown or nearly brown. Body elongate, gradually tapering 
to caudal end; greatest width at mesothorax. Front with broad median ridge on dorsal face; vertex narrow, two-fifths the length of prothorax. Clypeo-labral suture indistinct but labrum and pilifers well defined; basal part of labial palpi with a slight rugosity; labial palpi two-fifths the length of maxillae; maxillae extending over three-fifths the distance between tips of prothoracic legs and antennae; mesothoracic legs extending to fairly before tips of forewings; hindwings reaching cephalic margin of 4th abdominal segment. Prothorax concave on each side of a carinate median ridge; alar furrows on mesothorax very conspicuous. Abdominal segment 1 with two setae on dorsum; the spines of cephalic row on 2nd abdominal segment short and weak, those of 3rd abdominal segment not strong; those of 8 th abdominal segment very stout and projected vertically to body; 9 th abdominal segment with two to seven spines on each side of dorsum in the male, zero to three in the female. Abdominal segments 6,7 and 8 in the male, 6 and 7 in the female each with a rugged transverse row on ventre, the row of 6 th abdominal segment weak in both sexes, those of 7 th and 8 th abdominal segments in the male, 7 th in the female prominent and projected. Ventral suture between 8th and 9th abdominal segments distinct in the male. Abdominal segment 10 with eight spines on ventre, zero to two on dorsum. Each of the spines usually has a short seta. Proleg scars visible on 4 th-6th abdominal segments, those of 4 th abdominal segment usually united with each other, consequently represented by a transverse line. Anal opening slit-like in both sexes.

Length: Male $17-21 \mathrm{~mm}$., female $20.23 \mathrm{~mm}$. Width: Male 4.8 5.2 $\mathrm{mm}$., female 5-5.2 $\mathrm{mm}$.

Bionomics. (Pl. 12, figs. 5, 6, 7, 8, 9)

Food plants: Vitis labruscana Bailey (Vitaceae), V. vinifera L. (Vitaceae), V. thunbergii Sieb. et Zucc. (Vitaceae), V. coignetiae Pulliat (Vitaceae).

Shinji (1944) has recorded the species as causing the galls on $V$. coignetiae, and Kikuchi (1933) observed that Populus maximowiczii Henry (Salicaceae) had been infested by the larva of this species in Manchuria. Usually the larva of this species feeds upon V. labruscana, $V$. vinifera and $V$. thunbergii in Japan.

The moth emerges from the end of April to June, mostly in May. The eggs are usually laid singly in May and June on the vine, both surfaces of the leaf, the base of the sprout or the petiole of the leaf. Two eggs are found together on rare occasions. The egg is reddish brown, ellipsoidal in shape and somewhat flat and slightly concave on the upper surface, and has polygonal (usually hexagonal) sculptures. The egg period is five to ten days. The newly hatched larva is 2.5 $\mathrm{mm}$. long and bores into the vine, often the basal part of the sprout. The distal part of the young vine, which is growing at that time and 
into which the larva bores begins usually to wither. The part occupied by the larva is gradually expanding out and forming a gall-like swelling either slightly or conspicuously according to the food plants. The larva bores a tunnel in a vine and makes an opening through which the larva discharges out its frass. Sometimes several galls produced by the larvae on $V$. thunbergii are observed within relatively short length of a vine, the distance between two galls in such cases being about $70.150 \mathrm{~mm}$. In a vine about $250 \mathrm{~mm}$. in length as many as five larvae were observed. Rarely two or more galls entirely adjoin with each other and it is difficult to distinguish the two galls superficially. Untill the end of summer the larva nearly come to maturity. In Kyushu district, the larva begins to close the opening of its gall by a membrane or minute woody fragments in autumn (September and October).

The gall caused on $V$. labruscana and $V$. vinifera show a slight swelling, about 1.2 times as broad as the normal vine, sometimes does not show a swelling, entirely so in the perennial vine. The gall caused on $V$. thunbergii usually shows rather prominent swelling, $50-70 \mathrm{~mm}$. in length, $8-15 \mathrm{~mm}$. in width and $3-6 \mathrm{~mm}$. in normal vine width. The tunnel of the larva differes in length according to the food plants. In $V$. labruscana and $V$. vinifera it is very long, and one or both ends are filled with small, reddish pellets of frass and woody fragments. In $V$. thunbergii it is rather short, usually shorter than the length of the gall and contains rather little pellets.

In the larval chamber (a tunnel which is short or long) the larva winters. In February and March the larva utilize usually the upper part of its tunnel as a pupal chamber. The larva enlarges an opening which is used as an exit hole for the future adult and makes a lid of the pupal chamber just inside the exit hole. Sometimes the larva bores another hole aside from the opening which was used before and closed at that time. From the end of March to April in the western part of Japan, the larva transforms to the pupal stage. The pupa faces the lid and directs to the base of a vine, rarely to the distal end. The lid of the chamber is located between the exit hole and pupa. The pupa on emergence pushes the lid but does not break it, and protrudes its cephalic half from an exit hole. There is but one generation a year.

For the control of this species working in $V$. labruscana and $V$. vinifera the author wishes to emphasize the following point. The cultivator of vineyard usually overlooks the fact that the larva bores even into an old vine, a perennial vine, which is not the object of the ordinary pruning in winter and shows nothing in swelling. 


\section{Paranthrene yezonica Matsumura, 1931}

Paranthrene yezonica Matsumura, 6000 Ill. Ins. Jap.: 1017, no. 1866, 1931; Gaede, in Seitz. Gross-Schmett. Suppl. 2: 231, 1933; Inoue, Check List Lep. Jap. 1: $45,1954$.

Paranthrene (Nokona) yezonica Matsumura, Ins. Mats. 6(1): 7, 11, pl. 1, fig. 18, 1931.

Male. (Pl. 11, fig. 3; Pl. 14, figs. 3, 4)

Antennae shiny purplish black above, reddish brown beneath. Vertex with long black hairs; frons greyish white. Occipital fringe orange above. Labial palpi burly; first joint black; second and third ones black basally and behind, orange in front and inner sides. Thorax black, the sides and sometimes anterior margin of prothorax yellow; patagia shiny black, a patch at the base of forewings orange; mesoand metathorax each with two orange patches on dorsum posteriorly; metathorax with long yellowish hairs close to the base of hindwings. Forewings purplish black with metallic gloss and slightly mixed with reddish brown scales. Hindwings transparent, slightly tinged with yellow; veins and margins dark brown with metallic gloss; discocellulars broadly scaled. Fringes of both wings dark brown. Vein 3 of hindwings from just before angle of cell and vein 4 from the angle. Underside of forewings scattered with reddish brown scales, heavily on the outer end of cell; hindwings with veins reddish brown, discocellulars with reddish brown scales broadly. Legs black; distal ends of fore coxae and trochanters yellow; fore femora and tibiae with long hairs posteriorly; fore tarsi yellowish; mid and hind trochanters yellow; mid and hind femora with long white hairs posteriorly, and the latter bordered with yellowish white posteriorly; hind tibiae yellowish posteriorly; mid and hind tarsi yellowish white beneath. Abdomen black with a fine orange band on the posterior margin of 4 th and 6 th abdominal segments, the former band being very broad and occupied almost the segment and encircling, the latter about half as broad as the length of the segment and only above and sides. Anal tuft black with paired tufts of hairs, and slightly mixed with brown. Genitalia: a narrow ventral plate gradually broadening towards the base; gnathos stout with three somewhat larger projections than those of $P$. regale; juxta rather distinct; valva elongate-ovate, clothed with palmate spines somewhat densely and widely than $P$. regale; aedoeagus with a downward-pointed hook just below the apex.

Female. (P1. 11, fig. 4 ; Pl. 16, fig. 2)

Abdomen with the same orange bands as the male. Anal tuft black, flat. Genitalia: corpus bursae elongate, without signum, finely transversely wrinkled, reticulate only at the extremity.

Length of forewing: Male $13-16 \mathrm{~mm}$., female $19 \cdot 18 \mathrm{~mm}$.

Specimens examined: 250 \& 19, Fukuoka, Fukuoka Pref., 13-16. 
vi. 1957, 6 站含 \& 3 우, ibid., 5-18. vi. 1958, reared by K. Yano (food plant: Ampelopsis heterophylla); 1 s \& 15 우우, ibid., 13-19. vi. 1957, K. Yano leg.; 1 s, Itoshima, Fukuoka Pref., 5. vi. 1958, reared by K. Yano (food plant: Vitis thunbergii); 1\%, Mt. Iwawaki, Osaka Pref., 29. vi. 1954, A. Mutuura leg.

Habitat: Japan (Hokkaido, Honshu and Kyushu).

This species was originally described by Matsumura (1931a) by a single male specimen collected at Otaru, Hokkaido. In the same year he gave a brief redescription of it, but afterwards no specimen had been reported.

Mature larva. (Pl. 19, figs. 9, 11)

Closely allied to $P$. regale. Head with seta A2 slightly nearer to A1 than Aa. Mandible similar to that of $P$. regale but with a distinct furrow at the ventral surface. Crochets of ventral prolegs somewhat fewer in number than those of $P$. regale, $14 \pm$ in a row. Otherwise like $P$. regale.

Pupa.

Extremely similar to $P$, regale but slightly larger than that species. Maxillae, rarely and especially in the male, nearly reaching tips of antennae. Dorsal spines of 9 th abdominal segment more variable in number than in $P$. regale, zero to three on each side in both sexes, sometimes entirely without it in the female. Abdominal segment 10 with four broad spines on ventre in both sexes, zero to two on dorsum in the female, without or rarely with a minute spine on each side in the male.

Bionomics. (Pl. 13, figs. 1, 2, 3, 4)

Food plants: Ampelopsis heterophylla Sieb. et Zucc. (Vitaceae), Vitis thunbergii Sieb. et Zucc. (Vitaceae).

The moth appears from the end of May to June. The life history of this species, a wild grapevine borer, is closely allied to that of $P$. regale. The gall caused by the mature or nearly mature larva on A. heterophylla shows a fairly conspicuous swelling, $45-75 \mathrm{~mm}$. in length, $7.11 \mathrm{~mm}$. in width and $4-7 \mathrm{~mm}$. in normal vine width. There is a single annual generation. The author has not seen this species attacking $V$. labruscana or $V$. vinifera but if it is established in the vineyard, this species will become a menace to the viticulture.

\section{Paranthrene pernix (Leech, 1888)}

Bembecia pernix Leech, Proc. Zool. Soc. Lond. 1888: 592, pl. 30, fig. 5, 1888; Matsumura, Cat. Ins. Jap. 1: 188, 1905; Dalla Torre et Strand, Lep. Cat. $31: 179,1925$.

Sciapteron bicincta Leech (nec Walker), Proc. Zool. Soc. Lond. 1888: 592, 1888.

Paranthrene bicincta Bartel (nec Walker), in Seitz. Macrolep. (Pal.) 2: 380, pl. 50, fig. k, 1912; Hampson, Novit. Zool. 26: 102, 1919 (partim); Dalla Torre 
et Strand, ibid.: 155, 1925 (partim); Matsumura, 6000 Ill. Ins. Jap: 1015, no. 1860, 1931: Matsumura, Ins. Mats. 6(1): 11, pl. 1, figs. 17, 25, 1931; Esaki, IIori et Yasumatsu, Ins. Jap. I1l. Icon. Col. Nat. Dep.: 158, pl. 91, fig. 283-2, 1938; Kawata, Icon. Ins. Jap. (rev. ed.): 557, fig. 1535, 1950; Inoue, Check List T.ep. Jap. 1: 45, 1954 (partim).

Chamaesphecia pernix Bartel, ibid.: 409, pl. 51, fig. k, 1912.

Paranthrene parnix Le Cerf, in Oberthür. Etud. Lep. comp. 14: 260, 1917; Hampson, iisitl.: 106, 1919; Dalla Torre el Strand, ibid.: 161, 1925; Gaede, in Seit\%. Gross-Schmett. Supjl. 2: 231, 1933; Kawada, ibid.: 557, fig. 1534, 1950 ; Inote, ibid.: 45, 1954; Inoue, Icon. Het. Jap. Col. Nat. 1: 153, pl. 27, fig. 800, 1957; Shirôzu, Icon. Ins. Jap. Col. Nat. Ełł 1: 229, pl. 164, flg. 9, 1959.

Paranthrene hirayamai Matsumura, 6000 I11. Ins. Jap.: 1016, no. 1862, 1931; Matsumura, Ins. Mats. 6(1): 7, 11, pl. 1, fig. 23, 1931; Gaede, ibid.: 231, 1933; Inoue, ibid.: 45, 1954. Syn. nov.

Afgeria bicincta Hori (nec Walker), Kontyû $8(3)$; 123, pl. 1, fig. A, 1934.

Male. (PI. 11, fig. 5; PI. 14, figs. 5, 6)

Antennae purplish black above, brown beneath. Vertex black; frons white at each side. Occipital fringe white, yellow above. First joint and outer sides of second and terminal ones of labial palpi blackish brown, remaining parts yellow; sometimes almost entirely yellow. Thorax black; anterior margin of prothorax narrowly yellow; tegulae indistinctly edged with yellow; pro- and mesothorax on each side, a spot close to the base of forewings reddish brown. Forewings reddish brown; costa, veins, outer margin dark brown; a small transparent area at the base; fringes greyish brown. Hindwings transparent; costa, veins, outer margin broadly, inner margin narrowly dark brown; discocellulars broad mixed with reddish brown; fringes greyish brown, white at the base of inner margin. Vein 3 of hindwings from just before the angle of cell or rarely from the angle with vein 4 . Underside of forewings yellow at the costa; hindwings with discocellulars entirely reddish brown. Legs black; fore femora and tibiae posteriorly edged with long black hairs; mid and hind trochanters yellowish white; mid and hind femora posteriorly bordered with long white hairs; all tarsal joints yellow at their ends. Abdomen black; 2nd and 4th abdominal segments moderately and 6 th and 7 th abdominal segments narrowly banded posteriorly with yellow above and sides; yellow band of 4 th abdominal segment slightly broader than that of 2nd abdominal segment and continuing beneath; sometimes 2nd abdominal segment with a pale yellow longitudinal stripe beneath; posterior margins of 3rd, 5th and 6th abdominal segments slightly touched with yellow beneath. Anal tuft well developed, fan-shaped, black, edged with white. Genitalia: gnathos distinct, with a median deep incision; juxta rhombic; saccus spoon-shaped at the tip; valva elongate-ovate, its costal area widely clothed with inwardly directed palmate spines, ventral margin with hairs thickly, terminating in the sacculus ridge which is clothed massively with strong spines; aedoeagus without a downward-pointed 
hook near the apex.

Female. (Pl. 11, fig. 6; Pl. 16, fig. 3)

Hindwings with fringes entirely greyish brown. Abdomen banded with deep yellow on 2nd and 4th abdominal segments, and more narrowly with pale yellow on 6th abdominal segment, the band of 4 th abdominal segment about twice as broad as that of 2nd abdominal segment. Anal tuft flat, black, with two deep yellow longitudinal stripes above. Otherwise like the male. Genitalia: corpus bursae elongate, transversely wrinkled about one-third basally or often without it, signum not found.

Length of forewing: Male $11-13 \mathrm{~mm}$., female $12-15 \mathrm{~mm}$.

Specimens examined: 1 क (type of $P$. hirayamai Mats.) labelled “Komaba, Tokyo, Japan, 5-9-1914, S. Hirayama”; 7 s今 \& 8 \%, Fukuoka,

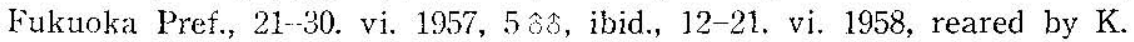

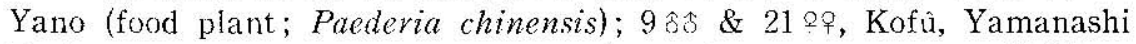
Pref., 3 9. vi. 1958, T. Saigusa leg. (larvae) and reared by K. Yano (food plant: $P$, chinensis); $1 \hat{0}$, Satamisaki, Kagoshima Pref., 7. vii. 1958, reared by K. Yano (food plant: $P$. chinensis); 1 \& \& 3 \% , ibid., 23-24. vi. 1957, H. Kamiya and T. Saigusa leg. Many other specimens were examined.

Habitat: Japan (Honshu and Kyushu).

This species was described by two males from Shimonoseki and Oiwake. The female of the species is closely allied to $P$. bicincta (Walker) which was described from N. China and its male has not been reported. It is difficult to distinguish both females superficially. Up to the present, the female of the species from Japan has not recorded under the name $P$. pernix, but it has been dealt as $P$. bicincta. Matsumura (1931a, b) and Hori (1934) showed the both sexes of the species under the name $P$. bicincta. Through the kindness of $\mathrm{Mr}$. J. D. Bradley, the author could compare the sketches of the female genitalia of the type specimens of $P$. pernix and $P$. bicincta. The femaie of $P$. pernix may be separable from $P$. bicincta by the absence of signum on the corpus bursae. The author's opinion is that $P$. bicincta does not occur in Japan and $P$. pernix not in China. Besides, after careful examination of the type specimen of $P$. hirayamai Matsumura, the author has convinced that it is a synonym of $P$. pernix. There seems to be a considerable variation within the species regarding the degree of the development of the transverse wrinkles of the corpus bursae and the coloration of the labial palpi.

Mature larva. (Pl. 17, figs. 2, 7; Pl. 18, figs. 3, 4, 10, 14, 18, 22 ; Pl. 19, figs. 2, 15)

Body rather stocky, with deep intersegmental incisions. Head very small, considerably retracted within prothorax, broader than long; fronto-clypeal region (excluding anteclypeus) slightly shorter than half 
the length; boundaries of adfrontal area joining vertical triangle; frontal suture indistinct, especially towards vertical triangle. Labrum with a round anterior margin. Mandible with five teeth, outer three of which are sharply pointed, the fourth short and round, the last very small. Ocelli six, not formed in normal Aegeriid arrangement, viz. ocelli V and VI not scparated from the others; ocelli I, II and III forming a right angle at the ocellus II. Prothorax with somewhat round spiracles which are larger than those on abdomen. Spiracles on 8 th abdominal segment equal to those on 1st-7th abdominal segments in size. Pinacula on abdomen indistinct. Crochets of ventral prolegs $9+$ in a row, those on anal prolegs $6 \pm$ and usually sunk in the body wall. Ventral and anal prolegs sometimes with very small crochets. Body invested with minute spines as shown in P1. 19, fig. 15. Colour: head brown, leaving a broad pale yellow area along frontal suture and vertical triangle; anterior margin of clypeo-labra! region, adfrontal area and hind occipital margin of vertex dark brown. Body yellowish white or dirty white, sometimes darker before pupation; prothoracic shield and anal plate yellow, the former with a pale brown short stripe obliquely, the latter slightly scattered with brown spots anteriorly; pinacula nearly the same as ground colour. Crochets of ventral and anal prolegs brown, reddish brown at the extremity. Chaetotaxy: head with puncture $\mathrm{AFa}$ slightly nearer to $\mathrm{AF} 2$ than $\mathrm{AF} 1$, puncture $\mathrm{Pb}$ nearer to $\mathrm{V} 1$ than $\mathrm{P} 2$; setae $\mathrm{A} 1$ and $\mathrm{A} 2$ relatively approximate to each other; puncture $\mathrm{Oa}$ approximate to $\mathrm{O} 2$; minute seta between ocelli III and IV, sometimes falling-out. Prothorax with setae of $\mathrm{L}$ group adjacent to each other; $\mathrm{XDb}$ sometimes postero-dorsad from the level of XDa. Six setae composed of L group, SV group and V1 on 1st abdominal segment arranged nearly in a single row.

Length : $16-17 \mathrm{~mm}$. Head width: $1.9-2 \mathrm{~mm}$.

Pupa. (P1. 20, figs. 5, 6, 7, 8, 9)

Body yellowish brown, short, tapering from 6 th abdominal segment to caudal end of body; greatest width at 3rd or 4th abdominal segment. Front with a broad cephalic projection, rounded at dorsal face. Vertex narrow, with a shallow incision at cephalic margin. Labrum and pilifers distinct; labial palpi about two-thirds the length of maxillae; maxillae extending to three-fourths the distance between tips of prothoracic legs and antennae; mesothoracic legs well extending backwards but scarcely to the tips of forewings; metathoracic legs extending to middle of 6 th abdominal segment. Hindwings extending to or beyond cephalic margin of 4 th abdominal segment. Abdominal segment 1 with two setae on each side. The spines on abdomen small, pointed. The row of caudal margin on 7 th abdominal segment rarely but slightly present in the female. Abdominal segment 10 with twelve broad spines, ventral four of which are minute, and two smaller ones present on 
ventre in the female. Usually these spines have a short seta but sometimes falling-out. Proleg scars inconspicuous. The suture between 8 th and 9 th abdominal segments somewhat distinct on ventre in the male. Anal opening Y-shaped.

Length: Mále 11.8-13.6 mm., female $13-14 \mathrm{~mm}$. Width: Male 3.8. $4 \mathrm{~mm}$., female $4.4 \mathrm{~nm}$.

Bimomics. (Pl. 13, figs. 5, 6, 7, 8)

Food plants: Paederia chinensis Hance (Rubiaceae), Parthenocissus tricuspidata Planch. (Vitaceae).

The principal food plant of the larva is $P$. chinensis. Takeuchi (1955) reported $P$. tricuspidata as the food plant of the species and told the author that the plant had been infested by the larva only once. Pueraria hirsuta Mats. (Leguminosae) is attacked by the larva when it entwined with $P$. chinensis, but the case seems to be extremely rare.

The moth appears from June to the end of August, usually in June and July. The egg is reddish brown, ellipsoidal in shape somewhat flat and slightly concave on upper surface and has hexagonal (rarely pentagonal) sculptures. The larva bores into the vine of the food plant. The part of the vine occupied by the larva shows a very conspicuous gall-like swelling. The larva does not burrow beyond the length of its gall. The larva grows rapidly in the gall and becomes nearly full grown untill the end of August in Kyushu district and constructs a cocoon in the gall. The larva winters in its cocoon.

The gall of a mature larva is $25-38 \mathrm{~mm}$. in length, $6-12 \mathrm{~mm}$. in width. The cocoon is black, elongate and slightly concave on ventral side and consisting of a kind of skin which is lined with silk. Both ends of the cocoon are somewhat flat and provided with greyish white ridges. It is $14-16.5 \mathrm{~mm}$. long in the male, $15-17.2 \mathrm{~mm}$. in the female, $5.2-6.5 \mathrm{~mm}$. wide in both sexes and $4.7 .5 .1 \mathrm{~mm}$. high in the male, 5$5.2 \mathrm{~mm}$. in the female. Sometimes several galls approximate with each other in a vine. In such a case galls are usually united together, for example, four adults emerged from a gall which was $70 \mathrm{~mm}$. in length. Two larvae are frequently observed in a single gall. Sometimes the larva makes a gall which is composed by two entwined vines. The surface of a gall has often a broad crack or a rather large opening, but the larva almost closes these openings partly or entirely.

The larva pupates in a cocoon in the next spring. The pupa directs to the base of a vine. The pupa on transformation breaks a cocoon at the cephalic end and protrudes its cephalic half or almost entire body from the gall. To expand its wings fully the adult takes less than two or three minutes. There is but one generation a year. 


\section{Genus Conopia Hübner, 1827}

The genus Conopia Hübner has been represented by six species in Japan. The present paper deals with two new synonyms, one of which is of a Korean species. Consequently there occur five species in Japan, three of which are treated hereafter.

General characters to the following species.

Antennae slightly dilated near distal end, sometimes serrate; ciliate beneath in the male. Female antennae simple, with minute cilia beneath. Antennae of both sexes ending in a small hair tuft. Labial palpi erect, usually smooth; first joint sometimes brushy. Proboscis well developed. Vein $1 \mathrm{~b}$ of hindwings with a short basal fork. Upper half of discocellulars of hindwings scaled. Legs with posterior first tarsal joint smooth (with appressed scales) or rarely slightly thickened with subdecumbent or decumbent scales at its end. Anal tuft developed in the male, fan-shaped; indended at the centre in the female. Male genitalia: uncus large flaring lobe with bifurcate spines thickly; tegumen stout; gnathos projected from tegumen; juxta weakly or distinctly sclerotized and with two lateral arms which have minute hairs; valva elongate, clothed with bifurcate spines thickly leaving a naked area at sacculus and along sacculus ridge, sacculus ridge with stout spines which are bifurcate or undivided; aedoeagus bulbous at the base, rarely with cornuti. Female genitalia: sterigma heavily sclerotized; ductus bursae sclerotized towards ostium bursae; corpus bursae elongate without signum, rarely with it.

Mature larva.

Body cylindrical, rarely somewhat flat. Head broader than long, retracted within prothorax; vertical triangle very deep; frontal suture distinct and joining almost vertical triangle. Ocelli six on each side; ocelli I, II and III forming an acute angle at the ocellus II. Labrum with a slight median incision at the anterior margin and with two labral punctures. Epipharynx with two punctures; epipharyngeal shield well defined and divided into two parts. Mandible with five teeth. Crochets of ventral and anal prolegs in normal Aegeriid arrangement. Crochets slender or sometimes bulbous at the basal end. Crochets of ventral prolegs having a tendency of decreasing in number towards posterior segments; sometimes with very small crochets. Body invested with minute pointed spines and rounded or square-shaped marks except a sclerotized area and decreasing in density towards ventrally and posteriorly. Colour: head brown to reddish brown, with paler area adjacent to frontal suture and vertical triangle. Body yellowish white; prothoracic shield with oblique stripe. Anal plate scattered with brown spots. Chaetotaxy: head with setae of vertical group forming a straight line; P2 sometimes minute; puncture $\mathrm{Fa}$ on the level of $\mathrm{F} 1$ or slightly 
forward; $\mathrm{AF} 1$ very minute; $\mathrm{C} 2$ slightly mesad from $\mathrm{F} 1$; $\mathrm{A} 2$ nearer to $\mathrm{A} 1$ than $\mathrm{Aa}$ and postero-laterad from $\mathrm{A} 1$; $\mathrm{Oa}$ between $\mathrm{O} 2$ and ocellus IV, rarely ventrad from a line joining $\mathrm{O} 2$ and ocellus IV and slightly nearer to the former; a puncture between ocelli III and IV. Labrum with setae of lateral group not separated from a median group; seta M2 longer than M1. Epipharynx with epipharyngeal setae triangularly grouped near anterior lateral margin; epipharyngeal setae slender and pointed. Prothorax with punctures of microscopic XD group; seta SD2 usually nearer to SD1 than XD2; SV group bisetose or trisetose. Mesoand metathorax with small reddish brown patch just ventrad from seta L3. SD2 on abdomen extremely minute as microscopic seta; SV group of 7th abdominal segment bisetose; D1 slightly dorsad from D2 on 1st-4th abdominal segments, on the same level on 5th abdominal segment and slightly ventrad on 6 th 8 th abdominal segments.

\section{Pupa.}

Body elongate, cylindrical. Abdominal segments gradually tapering to caudal end. Cephalic end of body not pointed but front with prominent cephalic projection forming a curved ridge. Front with a rather broad median ridge and depressions at its sides on dorsal face. The dorsal face with two setae at depressions. Vertex narrow, with a narrow or broad median ridge and not over half the length of prothorax. Epicranial suture present. Clypeus with two pairs of setae and sometimes two small projections at caudal margin, in case without the latter, clypeo-labral suture discernible; labrum and pilifers somewhat elevated and with rugosity; labrum well defined, rarely with two setae; pilifers nearly defined; maxillary palpi clearly indicated, very large, elongate; labial palpi fairly elongate, somewhat sinuate at lateral margins and united at basal part; maxillae and antennae very long, the former extending beyond tips of mesothoracic legs, usually well beyond it, the latter well approximate to tips of forewings but not reaching tips; prothoracic legs represented by their coxae, tibiae and tarsi well defined, coxae with an inconspicuous median oblique suture; mesothoracic legs extending beyond tips of forewings, rarely slightly before; metathoracic legs represented by their tarsi and extending well beyond tips of mesothoracic legs, maxillae and wings. Thorax with a carinate median ridge but weak and inconspicuous at caudal half of mesothorax and metathorax; mesothorax with deep alar furrows on each side, and with a seta in each furrow; metathorax with a seta at cephalic extremity on each side. Prothorax with slit-like spiracles at caudo-lateral angles. Forewings elongate, pointed at tips, extending to 5 th or 6 th abdominal segment. Hindwings narrow, rarely extending tips of forewings. Abdominal segment 1 without spines but with two setae, rarely without setae; cephalic margins of 2 nd -8 th abdominal segments with a transverse row of spines on dorsum, the spines on 2nd and 3rd abdominal 
segments weak, especially on 2nd abdominal segment, on 4 th -8 th abdominal segments the spines very stout and pointed; abdominal segment 9 with also a prominent transverse row of spines on dorsum, the spines very stout. Caudal margins of 3 rd $\cdot 7$ th abdominal segments in the male, 3rd-6th segments in the female each with a transverse row of small spines on dorsum, rarely found at 2nd abdominal segment. Second-eighth abdominal segments with spiracles at sides, those of 8 th abdominal segment fairly dorsad from the level of the others, rarely slit-like. Abdominal segment 10 with eight very broad spines, each of the spines usually has a seta inserted near its tip. 'Two smaller spines usually present, one on each side of the meson. Proleg scars rarely discernible. Genital opening slit-like in both sexes, the sides of it somewhat elevated in the male. Anal opening slit-like in both sexes.

\section{Conopia hector (Butler, 1878)}

Aegeria hector Butler, Ill. Lep. Het. Brit. Mus. 2: 60, pl. 40, fig. 4, 1878; Leech, Proc. Zool. Soc. Lond. 1888: 592, 1888.

Sesia (Aegeria) hector Matsumura, Cat. Ins. Jap. 1: 187, 1905; Matsumura, Thous. Ins. Jap. Suppl. 3: 85, pl. 36, fig. 17, 1911.

Synanthedon hector Bartel, in Seitz. Macrolep. (Pal.) 2: 383, pl. 51, fig. d, 1912; Inoue, Check List Lep. Jap. 1: 45, 1954; Inoue, Icon. Het. Jap. Col. Nat. 1: 154, fig. 803, 1957.

Conopia hector Hampson, Novit. Zool. 26: 75, 1919; Matsumura, 6000 I11. Ins. Jap.: 1013. no. 1850, 1931; Matsumura, Ins. Mats. 6(1): 10, 1931; Kawada, Icon. Ins. Jap. (rev. ed.): 560, fig. 1542, 1950; Shirôzu, Icon. Ins. Jap. Col. Nat. Ed. 1: 229, pl. 164, fig. 7, 1959.

Male. (Pl. 11, fig. 7; Pl. 15, figs. 1, 2, 3)

Antennae black above, dark brown beneath. Vertex with long black hairs; frons dark brown, white at the sides. Occipital fringe yellow but almost black above. Labial palpi erect, extending beyond vertex; first and second joints yellow in front and at the inner sides, the remaining parts of these joints black; terminal joint nearly black. Thorax black; tegulae edged with yellow; mesothorax with yellow patches on the sides. Forewings transparent; costa, outer margin, hind margin and discocellulars all broadly and veins purplish black with gloss; between veins 11 and 12 and hind margin with yellow scales. Hindwings transparent; veins and margins purplish black; discocellulars scaled at upper half; fringes brown, white at the inner margin. Underside of forewings scattered with yellow at the costa and other parts; hindwings yellow at the costa. Legs purplish black; fore coxae distinctly yellow at the outer edge; fore femora and tibiae yellow beneath and the latter with long hairs posteriorly; mid tibiae yellow at the middle and extremity, the terminal end of mid tibiae thickened with rough scales; mid tarsi smooth and yellow at first joint, remaining joints posteriorly yellow. Abdomen black; 1st and 2nd segments with 
yellow longitudinal stripes laterally; 4th and 5 th abdominal segments ringed with yellow posteriorly, continuing and broadening beneath and almost contact with each other ventrally; 2nd abdominal segment with a very narrow posterior yellow band. Anal tuft black, mixed with pale orange at the margin. Genitalia: juxta distinctly sclerotized; valva elongate, apex nearly pointed, ventral margin concave, costal area thickly covered with bifurcate spines, leaving a naked area along the sacculus ridge; sacculus ridge prominent with a curved row of short black undivided spines, densely at its ventral end and reaching the area of bifurcate spines at its dorsal end; aedoeagus bulbous at the base and with a small upward projection just below the apex.

Female. (PI. 11, fig. 8; Pl. 16, figs. 4, 5)

Anal tuft centrally indended, black, mixed with pale orange hairs at the sides. Otherwise like the male. Genitalia: sterigma projected extremely and transversely waved; ostium bursae cup-shaped; ductus bursae sclerotized towards ostium bursae; corpus bursae elongate-ovate, without signum.

Length of forewing: Male 11-13 mm., female $12-15 \mathrm{~mm}$.

Specimens examined: 5 우우, Fukuoka, Fukuoka Pref., 18--30. vi. 1957, 2 s $\hat{s} \& 1$ \& , ibid., 12-15. vii. 1957, reared by K. Yano (food plant: Prunus yedoensis). Besides, 14 specimens (8 ôf \& 6 우우 $)$ were examined.

Habitat: Japan (Hokkaido, Honshu, Shikoku and Kyushu), Korea and Manchuria.

This species is widely distributed in Japan and is a serious pest of the various plants of the family Rosaceae. This species as well as C. tenuis had sometimes been placed in the genus Synanthedon Hübner. These species, however, have such a character not found in Synanthedon as the posterior first tarsal joint smooth at its end.

Mature larva. (Pl. 17, figs. 3, 8; P1. 18, figs. 5, 6, 11, 15, 19, 23; Pl. 19, figs. $3,10,13,16$ )

Body cylindrical. Epipharynx with two long oblique epipharyngeal shields. Mandible long, about two-thirds as broad as the length; with five teeth, outer three of which are pointed, the fourth rather small and the last minute. Crochets of ventral and anal prolegs slender, $15 \pm$ on ventral prolegs in a row, $10 \pm$ on anal prolegs, the latter sometimes sunk in the body wall. Body invested with minute pointed spines and marks; thorax and 1st 6 th abdominal segments with pointed spines; 7th-9th abdominal segments partly with the spines and partly with marks. Colour: head reddish brown with a yellow area adjacent to vertical triangle and extending about half-way of frontal suture, darkened at the anterior and ventral margins, paler towards mesad; frontal suture yellowish white joining vertical triangle; anteclypeus semitransparent yellow. Body yellowish white; prothoracic shield yellow with an oblique brown stripe; pinacula of meso- and metathorax 
and abdomen pale yellow and inconspicuous; anal plate yellowish brown scattered with brown spots. Crochets of prolegs reddish brown. Setae on body brown to yellowish. Chaetotaxy: head with puncture AFa between $\mathrm{AF} 1$ and $\mathrm{AF} 2$ but variable in position; $\mathrm{AF} 1$ extremely minute; $\mathrm{V} 2$ equidistant from $\mathrm{VI}$ and $\mathrm{Va}$ sometimes slightly nearer to the latter; $\mathrm{Pb}$ slightly mesad from $\mathrm{V} 1$; $\mathrm{P} 2$ prominent; $\mathrm{O} 1$ ventrad from a line joining ocelli II and III; A3 dorsad from a line joining ocelli I and II. Labrum with the anterior margin sinuate; setae M1 and M2 behind of the level of La1; M3 behind of La3 and rather well separated from M1 and M2. Prothorax with seta SD2 variable in position, usually antero-mesad from SD1, sometimes directly cephalad from SD1, rarely disappear; SV group trisetose. LI of 1st-7th abdominal segments antero-mesad from L2, sometimes directly mesad. Setae SV2 and SV3 of 2nd abdominal segment with common pinacula. L1 of 9th abdominal segment cephalad and slightly ventrad from SD1.

Length: $24-28 \mathrm{~mm}$. Head width: $2.8 \sim 2.9 \mathrm{~mm}$.

Pupa. (P1. 20, figs. 10, 11, 12, 13)

Yellowish brown. Greatest width at posterior part of mesothorax. Vertex narrow, one-third the length of prothorax. Clypeus with two small projections at caudal margin; labrum with two setae; pilifers discernible; maxillae and mesothoracic legs extending beyond tips of forewings; antennae not reaching tips of forewings; metathoracic legs usually extending beyond 5th abdominal segment in the male. Hindwings not extending to tips of forewings. First abdominal segment with two setae. Abdominal segment 2 rarely with an inconspicuous row of minute spines at caudal margin on dorsum. Spines of cephalic rows on 4th-9th abdominal segments very stout; the row of 9 th abdominal segment discontinuous on dorsum. Tenth abdominal segment with eight broad spines, each of these spines has a seta, and two smaller spines, one on each side of the meson. Proleg scars discernible.

Length: Male $14-15 \mathrm{~mm}$., female $14-16.2 \mathrm{~mm}$. Width : Male $3.8-5$ mm., female $4.2-5 \mathrm{~mm}$.

Bionomics. (P1. 13, fig. 9)

Food plants: Prunus yedoensis Matsumura, P. donarium Sieb. var. spontanea Makino, P. persica Batsch., P. mume Sieb. et Zucc., P. salicina Lindl., $P$. armeniae L. var. ansu Maxim., P. pseudo-cerasus Lindl., Pyrus simonii Carr., Malus pumila Mill. var. dulcissima Koidz., Chaenomeles sinensis Koehne, Acer palmatum Thunb. (Aceraceae), Diospyros kaki Thunb. (Ebenaceae).

All the food plants except the last two belong to the Rosaceae. Mishima (1950) mentioned that Diospyros kaki was infested by this species in Nara prefecture. It is the only record of the species on the infestation to that plant. Acer palmatum and Chaenomeles sinensis were only once listed as the food plants by Watanabe (1937) and Hirano 
(1937) respectively. The species is most injurious to Prunus yedoensis and $P$. persica in Kyushu district.

The moth emerges from the end of May to August in Kyushu district and flies actively. The egg is laid on the bark. The larva is found on the main trunk especially in the crack or knot. The part occupied by the larva does not show any swelling, but it is easily recognized by the small reddish brown pellets of frass and woody fragments which are discharged by the larva. The larva winters in young or middle instar stage. With the approach of spring, the larva feeds voraciously and bores under the bark making a broad winding galleries or cavities. At that time masses of resin are found in company with small pellets of frass and woody fragments on the surface of the bark occupied by the larva which lives in resins in the gallery. The larva, upon reaching maturity, prepares a cocoon in the gallery but near outside or rarely on the surface of the bark.

The cocoon is elongate and somewhat flat beneath, and made of minute pellets of woody fragments, $14-17 \mathrm{~mm}$. long and $5-7.2 \mathrm{~mm}$. wide. Here the larva transforms to the pupal stage. Just prior to the emergence the mature pupa protrudes its upper half from the bark. There is probably one generation a year.

\section{Conopia tenuis (Butler, 1878)}

Aegeria tenuis Butler, Ill. Lep. Het. Brit. Mus. 2: 60, pl. 40, fig. 8, 1878; Leech, Proc. Zool. Soc. L.ond. 1888: 592, 1888.

Sesia tenuis Matsumura, Cat. Ins. Jap. 1: 187, 1905.

Synanthedo' tenuis Bartel, in Seitz. Macrolep. (Pal.) 2: 383, pl. 51, fig. c, 1912; Inoue, Check List Lep. Jap. 1: 46, 1954.

Conopia tenuis Hampson, Novit. Zool. 26: 75, 1919; Dalla Torre et Strand, Lep. Cat. 31: 117, 1925; Matsumura, 6000 Ill. Ins. Jap.: 1014, no. 1854, 1931; Matsumura, Ins. Mats. 6 (1): 10, pl. 1, fig. 12, 1931 ; Shirozu, Icon. Ins. Jap. Col. Nat. Ed. 1: 229, pl. 164, fig. 8, 1959.

Male. (Pl. 12, fig. 1; Pl. 15, figs. 4, 5)

Vertex with black hairs; frons purplish black, white at the sides. Occipital fringe yellowish white, nearly black on dorsum. Labial palpi erect, first and second joints yellowish white or nearly white in front and at the inner sides, the remaining parts of these and terminal ones black. Thorax black; mesothorax with yellow patches on the sides. Forewings transparent, veins and margins purplish black with gloss; broad outer margin with yellow scales between each veins; hind margin and between veins 11 and 12 rarely streaked with yellow scales; discocellulars nearly straight and slightly incrassate anteriorly. Hindwings transparent, veins and margins purplish black; discocellulars scaled at upper half. Fringes of both wings brown, white at the inner margin of hindwings. Underside of forewings similar to the upper 
surface, yellow scales rather prominent than upper surface; hindwings yellow only at the costa. Legs purplish black, fore coxae broadly white at the outer half; fore femora yellow partly; fore tibiae with long hairs, pale orange beneath; mid and hind tibiae yellowish white at the middle and thickened with rough scales at the end; mid tarsi yellowish; hind tarsi smooth; spurs yellowish. Abdominal segments 2, 4 and 6 posteriorly each ringed with a very narrow yellow band above and sides; 4th abdominal segment ringed entirely beneath; the band of 6 th abdominal segment rather white; 1st and 2nd abdominal segments with narrow longitudinal yellow stripes at the sides. Anal tuft purplish black, fan-shaped. Genitalia : juxta weakly sclerotized; saccus broadened at the tip; valva elongate, apex rounded, nearly entirely covered with bifurcate spines; sacculus ridge with a curved row of short flat spines; aedoeagus with distal end slightly divided.

Female. (P1. 12, fig. 2; P1. 16, figs. 6, 7, 8)

Anal tuft centrally indended, purplish black with a yellowish white margin. Otherwise like the male. Genitalia: sterigma heavily sclerotized; ductus bursae sclerotized towards ustium bursae; corpus bursae long, rarely with signa as shown in Pl. 16, fig. 8 .

Length of forewing: Male 8-9 mm., female $8-10 \mathrm{~mm}$.

Specimens examined : 5 송 \& 2 우우, Kizu, Kyoto Pref., 9-26. v. 1958, reared by K. Yano (food plant: Diospyros kaki); 1 \& \& 6 우우, ibid., 16. v.-13. vi. 1958, Y. Matuda leg. (larvae and pupae) and reared by $\mathrm{K}$. Yano (food plant: D. kaki); 1 s, Jozankei, Hokkaido, 30. vi. 1958, S. Miyamoto leg.; 1 ㅇ, Monobe, Kochi Pref., 28. viii. 1958, M. Takahashi leg. In addition 4 specimens ( 2 s $s$ \& 2 우우) were examined.

Habitat: Japan (Hokkaido, Honshu, Shikoku and Kyushu), Korea and Manchuria.

This species is characterized by the three narrow yellow bands on abdominal segments 2,4 and 6 and genitalic characters.

Mature larva. (Pl. 17, figs. 4, 9; Pl. 18, figs. 7, 8, 12, 16, 20 ; Pl. 19, fig. 4)

Body cylindrical, somewhat flat. Head with a fronto-clypeal region (excluding anteclypeus) twice as long as broad. Labrum with the anterior margin nearly straight. Epipharyngeal shield comparatively shorter than those of $C$. hector and $C$. quercus. Mandible short and stout, with five teeth, outer three of which bluntly pointed, inner two small. Crochets of ventral and anal prolegs bulbous at the base, and sometimes with very small ones. Crochets of ventral prolegs variable in number, average number $11 \pm$ in a row for all prolegs but $13 \pm$ on 3rd abdominal segment, $12 \pm$ on 4 th-5th abdominal segments and $8 \frac{1}{\leftarrow}$ on 6 th abdominal segment respectively in a row. Anal prolegs with 7.-8 crochets. Body invested with pointed spines on thorax, 1st-9th abdominal segments with pointed spines anteriorly but more sparse than 
C. hector, with marks towards posterior margin. Colour: head brown with a yellow area adjacent to vertical triangle and extending to a point just before anterior end of frontal suture, darkened at the anterior margin of vertex, adfrontal area and fronto-clypeal region (excluding anteclypeus); anteclypeus semitransparent, yellowish white. Labrum pale dirty yellow, brown at the middle region. Body yellowish white; prothoracic shield pale yellow with an oblique brown stripe which is interrupted at the middle; pinacula pale yellow, inconspicuous on mesoand metathorax and abdomen; anal plate dirty yellow, bordered with yellowish white. Chaetotaxy: head with seta V2 nearer to V1 than V3; puncture $\mathrm{Pb}$ anterior to and slightly laterad from V1; seta $\mathrm{P} 2$ minute; O1 closely approximate to ocellus III; seta A3 on a line joining ocelli I, II and seta O2; Oa antero-ventrad from O2. Labrum with setae M1 and M2 forward of the level of La1; M3 slightly forward of the level of La3. Prothorax with seta L1 almost directly mesad from L3; SV group bisetose; SD2 sometimes well approximate to SD1.

Length : $16-18 \mathrm{~mm}$. Head width: $1.8-2 \mathrm{~mm}$.

Pupa. (P1. 21, figs. 1, 2, 3, 4, 5)

Yellowish brown. Cephalic ridgy projection of front broad; median ridge at dorsal face of front also broad. Vertex half as long as prothorax; clypeus with two small projections at caudal margin; pilifers discernible; maxillae well extending to nearly tips of metathoracic legs but not reaching tips; mesothoracic legs extending beyond tips of forewings; antennae extending nearly but a slightly before tips of forewings, in the female fairly before. Hindwings not extending to tips of forewings. Abdominal segment 1 with two setae on dorsum; the cephalic row of 2nd abdominal segment very weak and discontinuous at middle; the spines on cephalic margins of 4 th-9th abdominal segments sharply pointed. Tenth abdominal segment with eight broad spines, each of these spines has a seta. Spiracles on 8 th abdominal segment showing no distinct opening and nearly slit-like. Proleg scars indiscernible.

Length: Male $8-10 \mathrm{~mm}$, female $9.5 \mathrm{~mm}$. Width: Male 2.2-2.5 mm., female $3-3.2 \mathrm{~mm}$.

Bionomics. (Pl. 13, figs. 10,11, 12)

Food plant: Diospyros kaki Thunb. (Ebenaceae).

The author studied the life history of this species in Kinki district. The species is a persimon borer and causes a considerable damage. The life history is similar to that of $C$. hector except for some different habits mentioned below.

The adult appears from May to June, but one female was collected late in August in Shikoku. The larva bores under the bark, preferring the knot, the fork of branches and the base of a young shoot. The larva discharges out small reddish pellets of frass and woody fragments 
which serve to indicate the presence of the larva. When the larva bores under the basal part of a young shoot, it feeds around the base, thus causing an enormous injury.

The larva winters in the young or middle instar stage and is found at the inner part, which presents somewhat chamber-like, of their winding gallery. After hibernation the larva feeds rather prosperously but resins are not found at outside. From April the larva constructs a cocoon of minute woody fragments in the gallery.

The cocoon is $11-12 \mathrm{~mm}$. long and $4-4.5 \mathrm{~mm}$. wide, slightly broader than height. The transformation to pupal stage takes place in a cocoon. The emergence habit of the species is allied to that of $C$. hector. There is but one generation a year.

Infestations of the species have been found only in Kinki district. It is, however, possible that the infestation may spread to the other districts.

\section{Conopia quercus (Matsumura, 1911)}

Sesia quercus Matsumura, Thous. Ins. Jap. Suppl. 3: 86, pl. 36, fig. 19, 1911.

Synanthedon niphonica Bartel, in Seitz. Macrolep. (Pal.) 2: 388, pl. 50, fig. g, 1912.

Conopia quercus Hampson, Novit. Zool. 26: 72, 1919; Dalla Torre et Strand, Lep. Cat. 31: 116, 1925; Matsumura, 6000 Ill. Ins. Jap.: 1014, no. 1853, 1931; Matsumura, Ins. Mats. 6 (1) : 10, 1931; Kawada, Icon. Ins. Jap. (rev. ed.): 559, fig. 1541, 1950; Shirôzu, Icon. Ins. Jap. Col. Nat. Ed. 1: 229, pl. 164, fig. $6,1959$.

Conopia chibensis Matsumura, 6000 Ill. Ins. Jap. : 1013, no. 1847, 1931 ; Matsumura, Ins. Mats. 6 (1): 5, 10, pl. 1, fig. 20, 1931; Gaede, in Seitz. Gross-Schmett. Suppl. 2: 233, 1933. Syn. nov.

Conopia galloisi Matsumura, 6000 Ill. Ins. Jap.: 1013, no. 1849, 1931; Matsumura, Ins. Mats. 6 (1): 6, 10, pl. 1, fig. 4, 1931. Syn. nov.

Synantherlon quercus Gaede, ibid.: 233, 1933; Inoue, Check List Lep. Jap. 1: 46, 1954; Inoue, Icon. Het. Jap. Col. Nat. 1: 154, pl. 27, fig. 804, 1957.

Synanthedon galloisi Gaede, ibid.: 233, 1933.

Synanthedon chibensis Inoue, ibid.: 46, 1954.

Male. (Pl. 12, fig. 3; Pl. 15, figs. 6, 7)

Antennae blackish brown above, yellow beneath and above at a little before apex, the latter sometimes disappear. Vertex with yellow and dark brown scales, white at the sides. Occipital fringe yellow. Labial palpi upturned, entirely yellow, rarely touched with black at the sides of second and terminal joints. Thorax blackish brown, yellow on each side; mesothorax with three yellow longitudinal stripes; at the bases of forewings yellow; metathorax with long yellow hairs on dorsum and at the bases of hindwings. Forewings transparent, veins, costa, outer and hind margins and discocellulars blackish brown; hind margin, between veins 9 and 10, 11 and 12 and discocellulars outwardly orange; outer margin with yellow scales; veins 10 and 11 separate but closely 
approximate. Hindwings transparent, veins and margins blackish brown; discocellulars scaled at upper half; costa yellow but concealed by forewings; short basal fork of vein $1 \mathrm{~b}$ with long yellow hairs. Fringes of both wings brown except that the basal part of hindwings yellow. Legs yellow; fore and mid femora blackish brown beneath; fore tibiae thickened with hairs; mid femora edged with long yellow hairs; mid and hind tibiae yellowish and thickened with rough scales; mid tarsi smooth, yellowish; hind tarsi yellowish and slightly thickened with scales at the end of first joint. Abdomen blackish brown, all segments narrowly ringed with yellow posteriorly on dorsum, the rings of 2 nd 4 th abdominal segments or rarely 5 th abdominal segment broadened at sides; all segments yellowish beneath. Anal tuft rather elongate, flat, blackish brown, mixed with orange, yellow and white hairs. Genitalia: uncus large; juxta moderately sclerotized; saccus broadened and bifurcate at the tips; valva elongate, greatest width at about one-third from the apex, nearly entirely clothed with inwardly directed bifurcate spines, leaving a naked area along sacculus ridge; sacculus ridge very prominent, with a curved row of bifurcate spines, at the ventral end with undivided spines; aedoeagus with three or four small cornuti.

Female. (Pl. 12, fig. 4 ; Pl. 16, figs. 9, 10)

Antennae distinctly yellow above at a little before the apex, the remaining part similar to the male in colour. Anal tuft blackish brown, centrally deep indended, mixed with many orange, yellow and white hairs. Otherwise like the male. Genitalia: ostium bursae with two lobes; ductus bursae heavily sclerotized, broadened in ventral view and narrowed in lateral view at one-third from ostium bursae; the opening to ductus seminalis situated at two-thirds from ostium bursae; corpus bursae with minute scobinations.

Length of forewing: Male $12-14 \mathrm{~mm}$, female $12-16 \mathrm{~mm}$.

Specimens examined: $1 \hat{b}$ (type of C. galloisi Mats.) labelled "Corea, Taiyudong, 1925, E. Gallois"; 1 s (type of C. chibensis Mats.) labelled "Chiba-ken, Abiko, 9/vii. 1927, T. Oguma"; 2 bs \& 3 우우, Fukuoka, Fukuoka Pref., 19. vi.-2. vii. 1957, 2 우우, ibid., 18. ix. 1957, 9 占合 \& 4 우, ibid., 4 -28. vi. 1958, reared by K. Yano (food plant: Quercus glauca).

Habitat: Japan (Honshu, Kyushu and Yakushima) and Korea.

Posterior first tarsal joint of the species slightly thickened with scales at its end, but based upon the other characters the author prefers to place it in the genus Conopia at the present time. Having examined the type specimens of $C$. chibensis Matsumura from Japan and $C$. galloisi Matsumura from Korea, the author has convinced that these two species are synonyms of the present species.

Mature larva. (Pl. 17, figs. 5, 10; Pl. 19, figs. 5, 17, 18)

Body cylindrical. Labrum and mandible allied to those of $C$. hector. 
Crochets of ventral prolegs $15 \pm$ in a row; anal prolegs $13 \pm$. Crochets of prolegs somewhat stouter than that of $C$. hector. Body invested with minute pointed spines and marks densely as shown in P1. 19, figs. 17, 18. Thorax with dense pointed spines only; 1st-4th abdominal segments with dense pointed spines anteriorly, marks towards posterior margin; 5th-9th abdominal segments with pointed spines anteriorly and somewhat sparsely, as in $C$. hector, marks towards posterior margin. Colour: head reddish brown with a deep yellow area adjacent to vertical triangle; darkened at the anterior and ventral margins; frontal suture distinct, deep yellow, joining vertical triangle; anteclypeus semitransparent, yellowish white. Body yellowish white; prothoracic shield yellow with an oblique brown stripe which is somewhat broad and narrowed at the middle; pinacula of prothorax and 9th abdominal segment distinct and yellow, usually inconspicuous and pale yellow on meso-, metathorax and 1st-8th abdominal segments; anal plate yellowish brown scattered with brown spots. Chaetotaxy: head with seta P2 minute; V2 slightly nearer to V3 than V1; O1 between ocelli II and III and on a line joining ocelli II and III; A3 well dorsad from a line joining ocelli I and II; seta AF2 on the level of the extremity of fronto-clypeal region or little forward; AFa nearer to AF2 than AF1. Prothorax with puncture XDb postero-ventrad from XDa; seta SD2 postero-mesad from SD1; L3 postero-mesad from L1; setae of SV group bisetose.

Length : $25 \mathrm{~mm}$. Head width : $2.9-3 \mathrm{~mm}$.

Pupa. (P1. 21, figs. 6, 7, 8, 9, 10, 11, 12)

Body reddish brown or yellowish brown. Vertex slightly shorter than two-fifths the length of prothorax. Clypeo-labral suture discernible but clypeus without a projection at caudal margin; pilifers clearly indicated; maxillae extending well beyond tips of mesothoracic legs but not reaching tips of metathoracic legs, in the female rarely not reaching tips of mesothoracic legs; mesothoracic legs nearly extending to tips of forewings, in the female slightly before the tips; antennae extending to fairly before tips of forewings, in the female slightly over threefifths the distance between tips of pro- and mesothoracic legs. Hindwings extending to tips of forewings, rarely not so. Abdominal segment 1 without a seta. Abdominal segment 2 rarely with a transverse row of minute spines; in the female the row of 9 th abdominal segment somewhat sparser at the lateral ends of row than in the male. Abdominal segment 10 with eight broad spines, usually six of which have a seta, and two smaller ones, one on each side of the meson. In the female second spines (excluding smaller one) with minute projections, in the male inconspicuous. Proleg scars indiscernible. The sides of genital opening clearly elevated in the male.

Length: Male 14-15.5 mm., female $14-17 \mathrm{~mm}$. Width: Male 4-4.5 mm., female 4-5 mm. 


\section{Bionomics.}

Food plants: Quercus acuta Thunb., Q. serrata Thunb., Q. glauca Thunb., Shiia cuspidata Makino, Shiia sp.

All the food plants belong to the Fagaceae. Q. acuta was the first recorded food plant of this species in the original description. In 1917 Matsumura added Shiia sp. to the list of food plants. Afterwards various authors listed "the oak" or "Shiia sp." as the food plants. In Kyushu district its injury has been considerable to $Q$. glauca.

The moth emerges from June to September, mostly in June and July. The eggs are laid singly on the main trunk, preferring the cracks or scars. The female oviposits eggs one by one within a rather short distance of the bark. The larva feeds under the bark. The peculiar habits in the infestation by the species are as follows: a large number of larvae, ten or more, attack the same part of the bark which is located near the base of the tree trunk, often within $50 \mathrm{~cm}$. above the soil level. They feed voraciously around the trunk, consequently the injured part often completely encircles the trunk. The part occupied by the larvae usually shows swelling composed of fine pellets of woody fragments. The larva often attacks the same part of the trunk which was attacked by the other larva in the previous year. Often the larva hibernates in a chamber. From the next spring the larva feeds again. When the larvae injure very actively, the injured part becomes slightly wet with resin-like substance.

The larva constructs a cocoon consisting of minute pellets of woody fragments, $15-22 \mathrm{~mm}$. long and $5 \% 7.8 \mathrm{~mm}$. wide. From May the larva begins to pupate in a cocoon. Prior to the emergence the pupa opens a cocoon at the cephalic end and protrudes its cephalic half from a cocoon. The emergence hole of the cocoon is represented by a kind of lid which attaches to the cocoon at the end. The life cycle probably covers a year.

\section{LITERATURE CITED ${ }^{1}$}

Arakawa, Y. 1933. Works of Agr. Exp. Stat. S. Manchurian Railway Co., Yûgakujo. (in Japanese)*

Bartel, M. 1912. In Seitz. The Macrolepidoptera of the World (Pal.) 2: 375-416, pls. 50-52.

Butler, A. G. 1878. Illustrations of typical Specimens of Lepidoptera Heterocera in the collection of the British Museum 2:59, pl. 40.

von Dalla Torre, K. W. et Strand, E. 1925. Lepidopterorum Catalogus 31.

Engelhardt, G. P. 1946. The North American Clear-wing Moths of the Family Aegeriidae. Bull. U. S. Nat. Mus. 190.

1 Asterisk indicates the literature cited indirectly. 
Esaki, T., Hori, H. et Yasumateu, K. 1938. Insectorum Japonicorum Illustratio Iconographica Coloribus ad Naturam Deptica: 158, pl. 71. (in Japanese)

Gaede, M. 1933. In Seitz. Gross-Schmetterlinge der Erde. Suppl. 2: 229-240.

Hampson, G. F. 1919. A Classification of the Aegeriidae of the Oriental and Ethiopian Regions. Novit. Zool. 26: 46-119.

Heinrich, C. 1916. On the taxonomic value of some larval characters in the Lepidoptera. Proc. Ent. Soc. Wash. 18 (3) : 154-164.

Hinton, H. E. 1946. On the homology and nomenclature of the setae of lepidopterous larvae, with some notes on the phylogeny of the Lepidoptera. Trans. R. ent. Soc. Lond. 97 (1): 1-37.

Hirano, I. 1937. Shokubutsu Gaichú Mokuroku [List of Plant Injurious Insects] 10. (in mimeographed copy). (in Japanese)

Hori, H. 1934. [On two gall making species of the family Aegeriidae] Kontyu 8 (3) : 123-130, pl. 1. (in Japanese)

Inoue, H. 1954. Check List of the Lepidoptera of Japan 1: 45-46.

Inoue, H. 1957. Icones Heterocerorum Japonicorum in Coloribus Naturalibus 1: 152-154, pl. 27. (in Japanese)

Kawada, A. 1950. Iconographia Insectorum Japonicorum (rev. ed.): 556-560. (in Japanese)

Kikuchi, I. 1933. [Host plant of Paranthrene regalis Butler] The Entomological World 1 (2): 146. (in Japanese)

Kondo, T. et Miyahara, H. 1929. [On the grape clear wing moth and its control] Agriculture of Manchuria 1 (6). (in Japanese)*

Kondo, T. 1933. [Insect pests of fruit trees in Manchuria-XIV] Agriculture of Manchuria 5 (10). (in Japanese)*

Kuwayama, S. 1938. Reports on the distribution of principal insect pests of crops and investigations of the injury. Manshokoku Sangyobu Shiryo 33. (in Japanese)

Leech, J. H. 1888. On the Lepidoptera of Japan and Corea--Part II. Sect. I. Proc. Zool. Soc. Lond. 1888: 591-593, pl. 30.

Matsumura, S. 1905. Catalogus Insectorum Japonicum 1: 186-188.

Matsumura, S. 1911. Jllustrated Thousand Insects of Japan, Suppl. 3: 49-51, 8588. (in Japanese)

Matsumura, S. 1931a. 6000 Illustrated Insects of Japan: 1012-1018. (in Jaeanese)

Matsumura, S. 1931b. A list and new species of Aegeriidae from Japan. Ins. Mats. 6 (1) : 4-12, pl. 1.

Mishima, R. 1950. In Yuasa et Asuyama. Byogaichâ no Seitai to Bojo (Biology and Control of Insect Pests and Diseases]: 509-510. (in Japanese)

Mosher, F. 1916. A classification of the Lepidoptera based on characters of the pupa. Bull. Illin. Laborat. Nat. Hist. 12 (2).

Nomura, K. 1937. Studies on the Moth-Fauna of Manchuria. Festschr. $60 \mathrm{Ge}$ burts. Prof. Dr. E. Strand : 467-505.

Okamoto, H. 1924. The Insect Fauna of Quelpart Island (Saishiu-to). Bull. Agr. Exp. Stat., Gov.-Gen. Chosen 1 (2): 176, 220.

Peterson, A. 1951. Larvae of Insects 1: 82, pl. L6-L9.

Popescu-Gorj, A., Niculescu, E. et Alexinschi, Al. 1958. Fauna Republicii Populare Romine, Insecta 11 (1).

Shinji, O. 1944. Chûei to Chûei-konchû [Galls and Gall Insects]: 434-436. (in Japanese) 
Shirozu, T. 1959. Iconographia Insectorum Japonicorum Colore Naturali Edita 1: 229-230, pl. 164. (in Japanese)

Strand, E. 1915. H. Sauter's Formosa-Ausbeute: Noctuidae-Aegeriidae. Arch. f. Naturg. A. 8, 1915: 45-49.

Takeuchi, K. 1955. Coloured Illustrations of The Insects of Japan 2: pl. 29. (in Japanese)

Walker, F. 1864. List of the specimens of Lepidopterous insects in the collection of the British Museum 31 (Suppl. 1): 12.*

Watanabe, F. 1937. Nippon Jumoku Gaichu Sómokuroku [List of Insects Injurious to Trees]: 88-89. (in Japanese) 


\section{Explanation of Plates \\ Plate 11}

Fig. 1. Paranthrene regale (Butler), male.

Fig. 2. Ditto, female.

Fig. 3. P. yezonica Matsumura, male.

Fig. 4. Ditto, female.

Fig. 5. P. pernix (Leech), male.

Fig. 6. Ditto, female.

Fig. 7. Conopia hector (Butler), male.

Fig. 8. Ditto, female.

\section{Plate 12}

Fig. 1. Conopia tenuis (Butler), male.

Fig. 2. Ditto, female.

Fig. 3. C. quercus (Matsumura), male.

Fig. 4. Ditto, female.

Fig. 5. Paranthrene regale (Butler), gall (on Vitis labruscana Bailey).

Fig. 6. Ditto, gall and pupal shell (on V. labruscana Bailey).

Fig. 7. Ditto, gall (on V. thunbergii Sieb. et Zucc.).

Fig. 8. Ditto, gall and pupal shell (on V. thunbergii Sieb. et Zucc.).

Fig. 9. Ditto, gall in July (on V. thunbergii Sieb, et Zucc.).

\section{Plate 13}

Fig. 1. Paranthrene yezonica Matsumura, gall (on Ampelopsis heterophylla Sieb. et Zucc.).

Fig. 2. Ditto, gall showing a larva in winter (on A. heterophylla Sieb. et Zucc.).

Fig. 3. Ditto, gall and pupal shell (on A. heterophylla Sieb. et Zucc.).

Fig. 4. Ditto, gall showing a pupal shell (on A. heterophylla Sieb. et Zucc.).

Fig. 5. Paranthrene pernix (Leech), gall showing a cocoon (on Paederia chinensis Hance).

Fig. 6. Ditto, gall and two pupal shells (on $P$. chinensis Hance).

Fig. 7. Ditto, gall and pupal shell (on $P$. chinensis Hance).

Fig. 8. Ditto, cocoon and pupal shell (on P. chinensis Hance).

Fig. 9. Conopia hector (Butler), cocoon and pupal shell (on Prunus yedoensis Mats.).

Fig. 10. C. tenuis (Butler), injured part by the larva (on Diospyros kaki Thunb.).

Fig. 11. Ditto, pupal shell (on D. kaki Thunb.).

Fig. 12. Ditto, cocoon and pupal shell (on D. kaki Thunb.). 
Plate 14

Male genitalia

Fig. 1. Paranthrene regale (Butler)

Fig. 2. Ditto, aedoeagus.

Fig. 3. P. yezonica Matsumura

Fig. 4. Ditto, aedoeagus.

Fig. 5. P. pernix (Leech)

Fig. 6. Ditto, aedoeagus.

Plate 15

Male genitalia

Fig. 1. Conopia hector (Butler)

Fig. 2. Ditto, aedoeagus, lateral view.

Fig. 3. Ditto, aedoeagus, ventral view.

Fig. 4. C. tenuis (Butler)

Fig. 5. Ditto, aedoeagus.

Fig. 6. C. quercus (Matsumura)

Fig. 7. Ditto, aedoeagus.

Plate 16

Female genitalia

Fig. 1. Paranthrene regale (Butler)

Fig. 2. P. yezonica Matsumura

Fig. 3. P. pernix (Leech)

Fig. 4. Conopia hector (Butler)

Fig. 5. Ditto, lateral view.

Fig. 6. C. tenuis (Butler)

Fig. 7. Ditto, lateral view.

Fig. 8. Ditto, signa.

Fig. 9. C. quercus (Matsumura)

Fig. 10. Ditto, ductus bursae, lateral view.

\section{Plate 17}

Mature larva

Fig. 1. Paranthrene regale (Butler), frontal view of head.

Fig. 2. P. pernix (Leech), frontal view of head.

Fig. 3. Conopia hector (Butler), frontal view of head.

Fig. 4. C. tenuis (Butler), frontal view of head.

Fig. 5. C. quercus (Matsumura), frontal view of head.

Fig. 6. $P$. regale (Butler), lateral view of head.

Fig. 7. P. pernix (Leech), lateral view of head.

Fig. 8. C. hector (Butler), lateral view of head.

Fig. 9. C. tenuis (Butler), lateral view of head.

Fig. 10. C. quercus (Matsumura), ocellar area of head. 


\section{Plate 18}

\section{Mature larva}

Fig. 1. Paranthrene regale (Butler), labrum.

Fig. 2. Ditto, epipharynx.

Fig. 3. P. pernix (Leech), labrum.

Fig. 4. Ditto, epipharynx.

Fig. 5. Conopia hector (Butler), labrum.

Fig. 6. Ditto, epipharynx.

Fig. 7. C. tenuis (Butler), labrum.

Fig. 8. Ditto, epipharynx.

Fig. 9. P. regale (Butler), right mandible.

Fig. 10. P. pernix (Leech), right mandible.

Fig. 11. C. hector (Butler), right mandibit.

Fig. 12. C, tenuis (Butler), right mandible.

Fig. 13. $P$. regale (Butler), left ventral proleg of 6th abdominal segment.

Fig. 14. P. pemix (Leech), left ventral proleg of 5 th abdominal segment.

Fig. 15. C. hector (Butler), left ventral proleg of 6th abdominal segment.

Fig. 16. C. tenuis (Butler), left ventral proleg of 3rd abdominal segment.

Fig. 17. P. regale (Butler), left anal proleg.

Fig. 18. P. pernix (Leech), left anal proleg.

Fig. 19. C. hector (Butler), left anal proleg.

Fig. 20. C. tenuis (Butler), left anal proleg.

Fig. 21. P. regale (Butler), dorsal view of 10 th abdominal segment.

Fig. 22. I'. pernix (Leech), dorsal view of 10 th abdominal segment.

Fig. 23. C. hector (Butler), dorsal view of 10th abdominal segment.

\section{Plate 19}

\section{Mature larva}

Figs. 1-13. Chaetotaxy. Figs. 14-18. Body spines.

Fig. 1. Paranthrene regale (Butler), prothorax.

Fig. 2. P. pernix (Leech), prothorax.

Fig. 3. Conopia hector (Butler), prothorax.

Fig. 4. C. tenuis (Butler), prothorax.

Fig. 5. C. quercus (Matsumura), prothorax.

Fig. 6. P. regale (Butler), mesothorax.

Fig. 7. Ditto, 2nd abdominal segment.

Fig. 8. Ditto, 3rd abdominal segment.

Fig. 9. P. yezonica Matsumura, 7th abdominal segment.

Fig. 10. C. hector (Butler), 7 th abdominal segment.

Fig. 11. P. yezonica Matsumura, 8th abdominal segment.

Fig. 12. $P$. regale (Butler), 9th abdominal segment.

Fig. 13. C, hector (Butler), 9th abdominal segment.

Fig. 14. $P$. regale (Butler)

Fig. 15. l'. pernix (Leech)

Fig. 16. C. hector (Butler)

Fig. 17. C. quercus (Matsumura)

Fig. 18. Ditto. 


\section{Plate 20}

\section{Pupa}

Fig. 1. Paranthrene regale (Butler), male, ventral view.

Fig. 2. Ditto, male, lateral view.

Fig. 3. Ditto, male, dorsal view.

Fig. 4. Ditto, male, dorsal view of 5th abdominal segment.

Fig. 5. P. pernix (Leech), male, ventral view.

Fig. 6. Ditto, male, lateral view.

Fig. 7. Ditto, male, dorsal view.

Fig. 8. Ditto, male, dorsal cephalic row of spines of 5th abdominal segment.

Fig. 9. Ditto, female, ventral view of caudal end of body.

Fig. 10. Conopia hector (Butler), male, ventral view.

Fig. 11. Ditto, male, lateral view.

Fig. 12. Ditto, male, dorsal view.

Fig. 13. Ditto, male, dorsal view of 5 th abdominal segment.

\section{Plate 21}

\section{Pupa}

Fig. 1. Conopia tenuis (Butler), male, ventral view.

Fig. 2. Ditto, male, lateral view.

Fig. 3. Ditto, male, dorsal view.

Fig. 4. Ditto, male, dorsal cephalic row of spines of 5 th abdominal segment.

Fig. 5. Ditto, female, ventral view of caudal half of body.

Fig. 6. C. quercus (Matsumura), male, ventral view.

Fig. 7. Ditto, male, lateral view.

Fig. 8. Ditto, male, dorsal view.

Fig. 9. Ditto, female, dorsal cephalic row of spines of 5 th abdominal segment.

Fig. 10. Ditto, female, ventral view of caudal half of body.

Fig. 11. Ditto, female, lateral view of caudal end of body.

Fig. 12. Ditto, female, dorsal view of caudal end of body. 


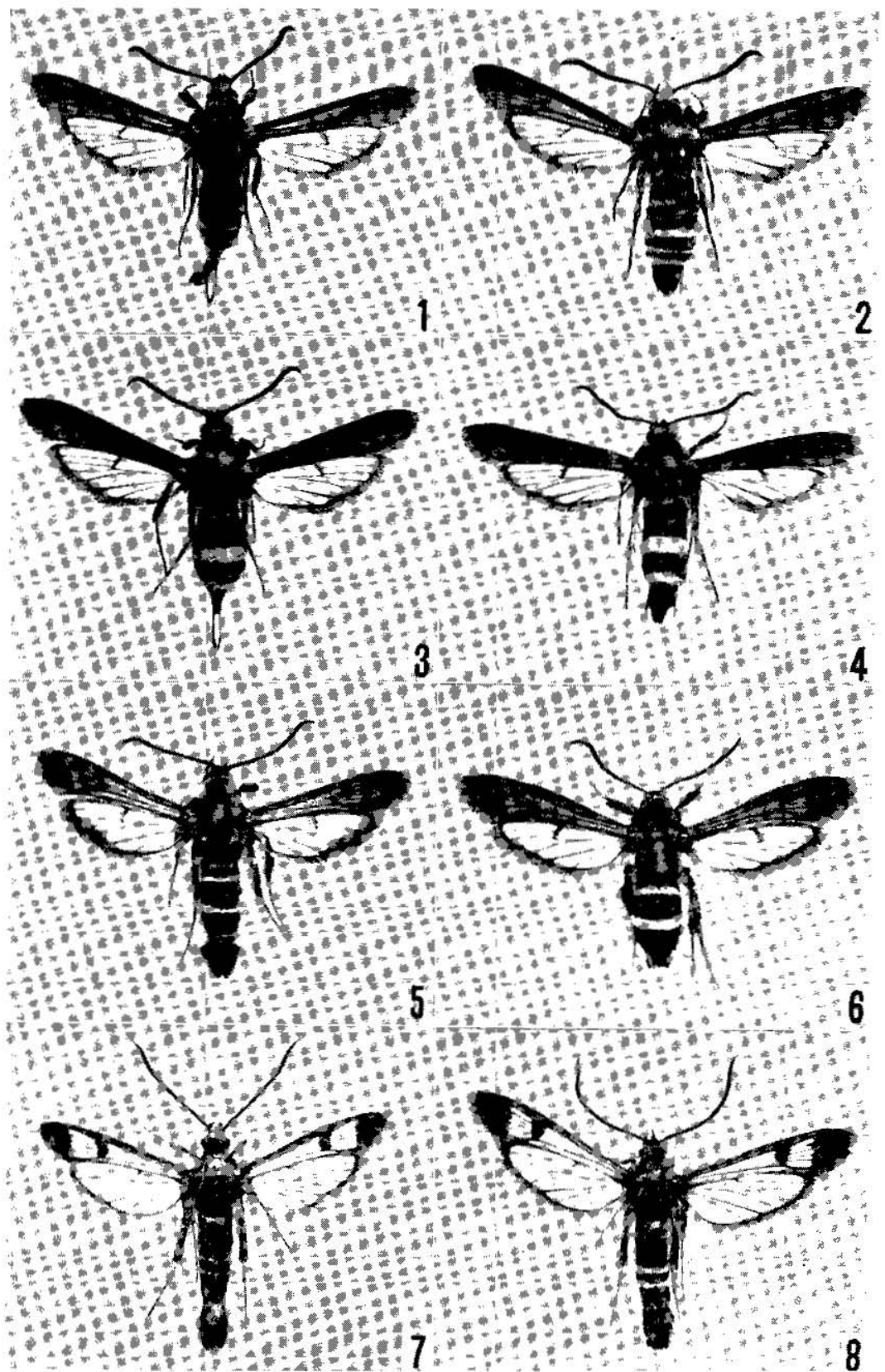

The genera Paranthrene and Conopia from Japan 


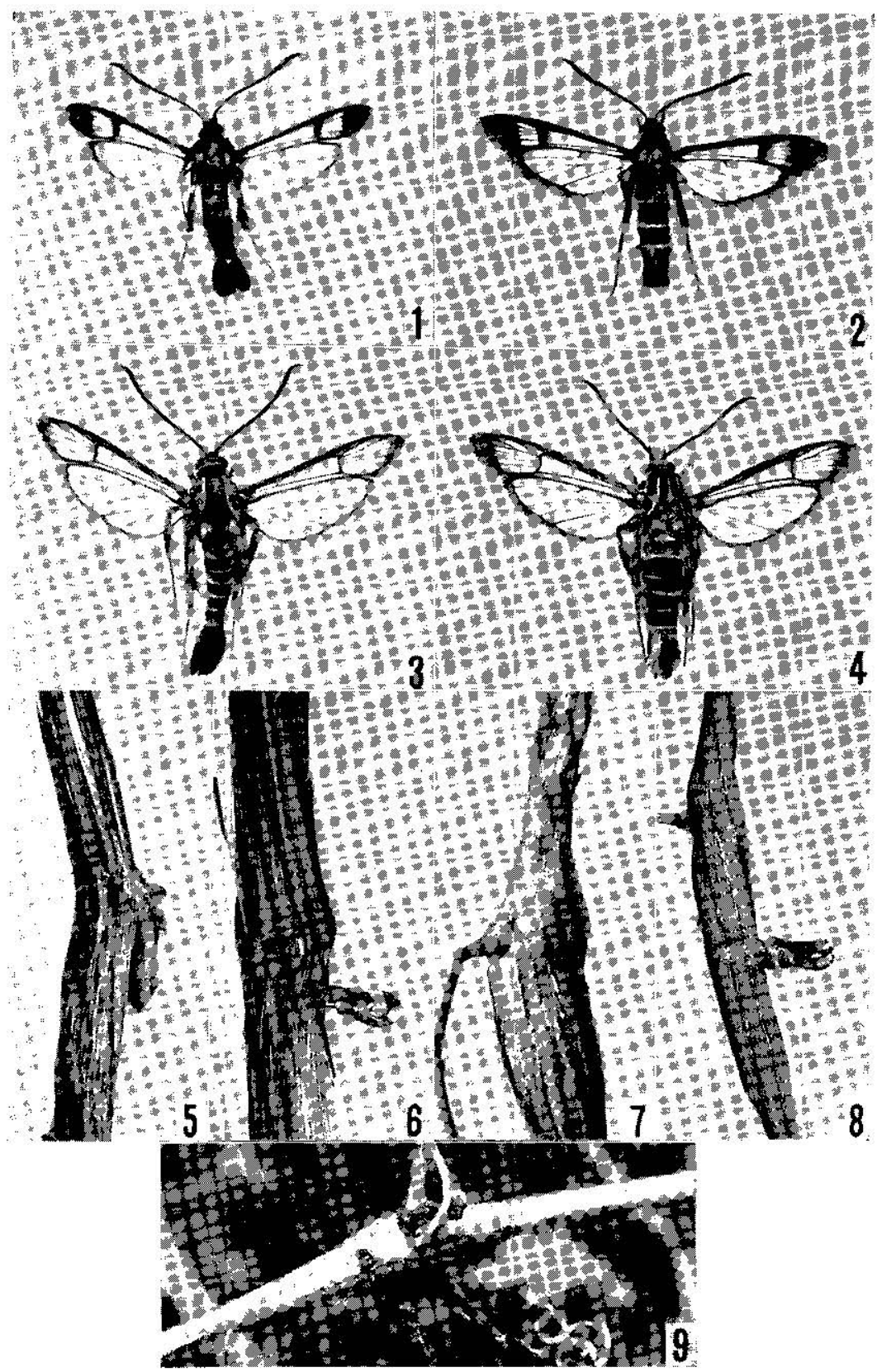

The genera Paranthrene and Conopia from Japan 


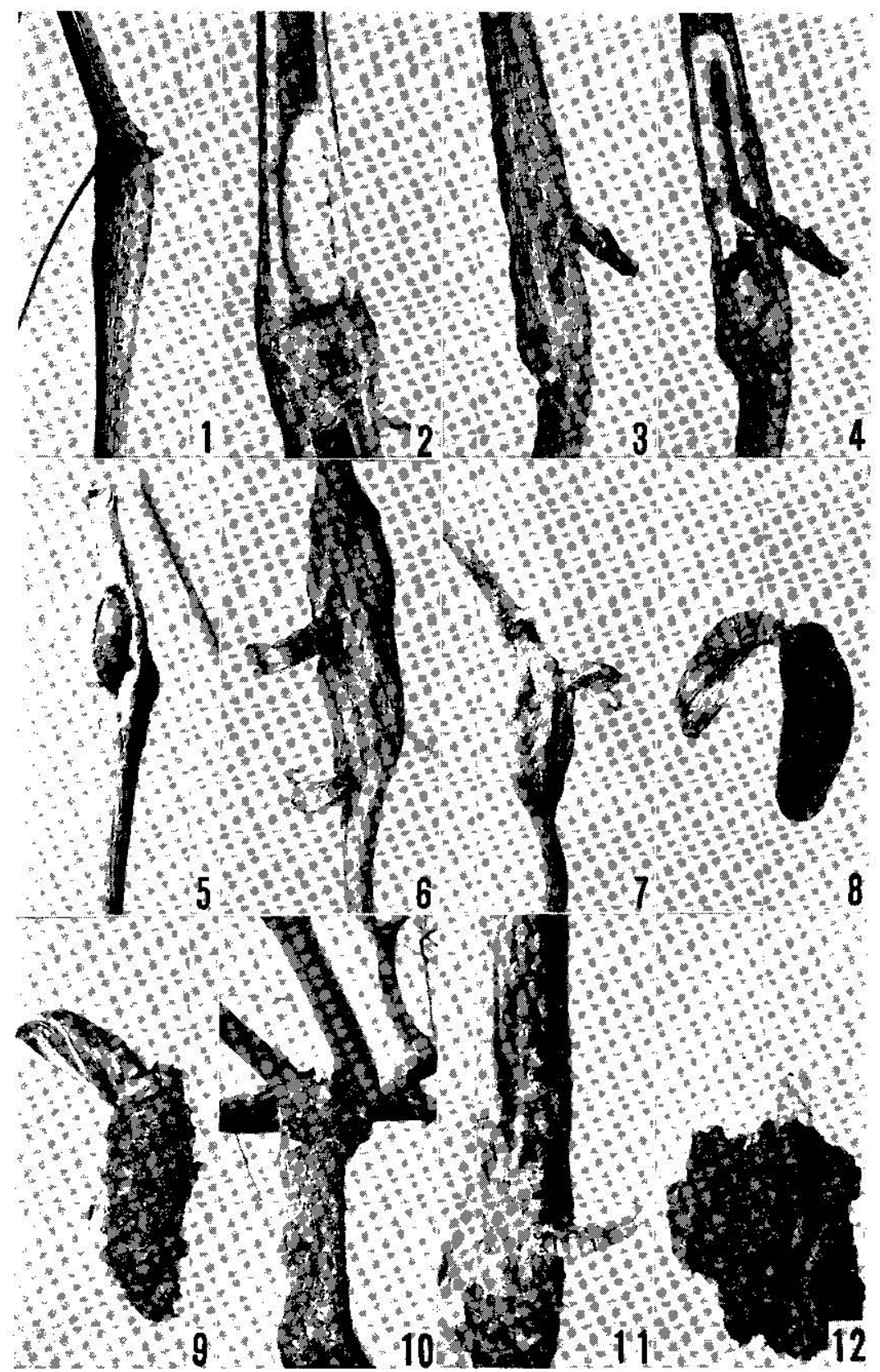

The genera Paranthrene and Conopia from Japan 
Jour. Fac. Agric., Kyushu Univ., Vol. 11

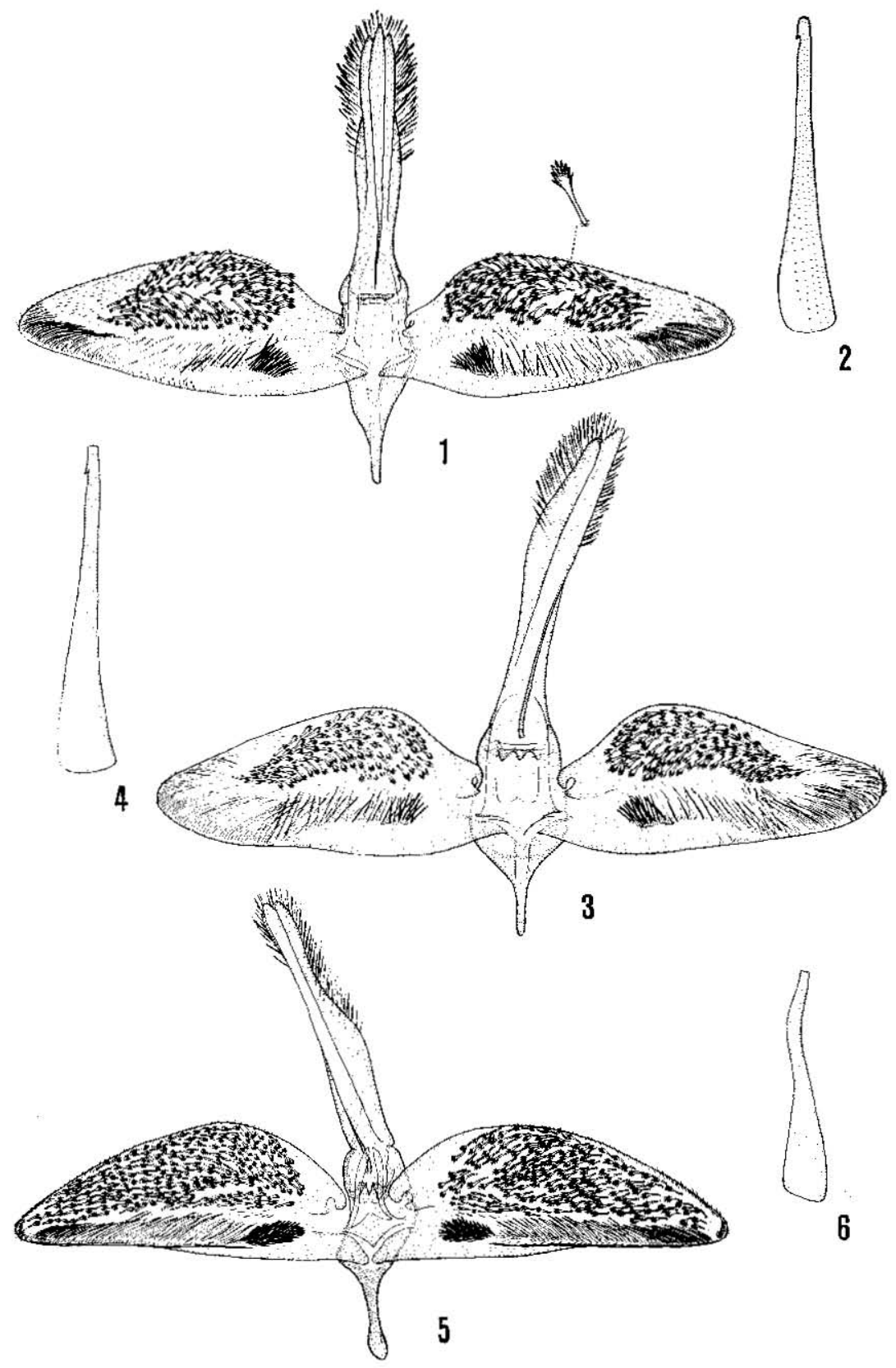

The genera Paranthrene and Conopia from Japan 


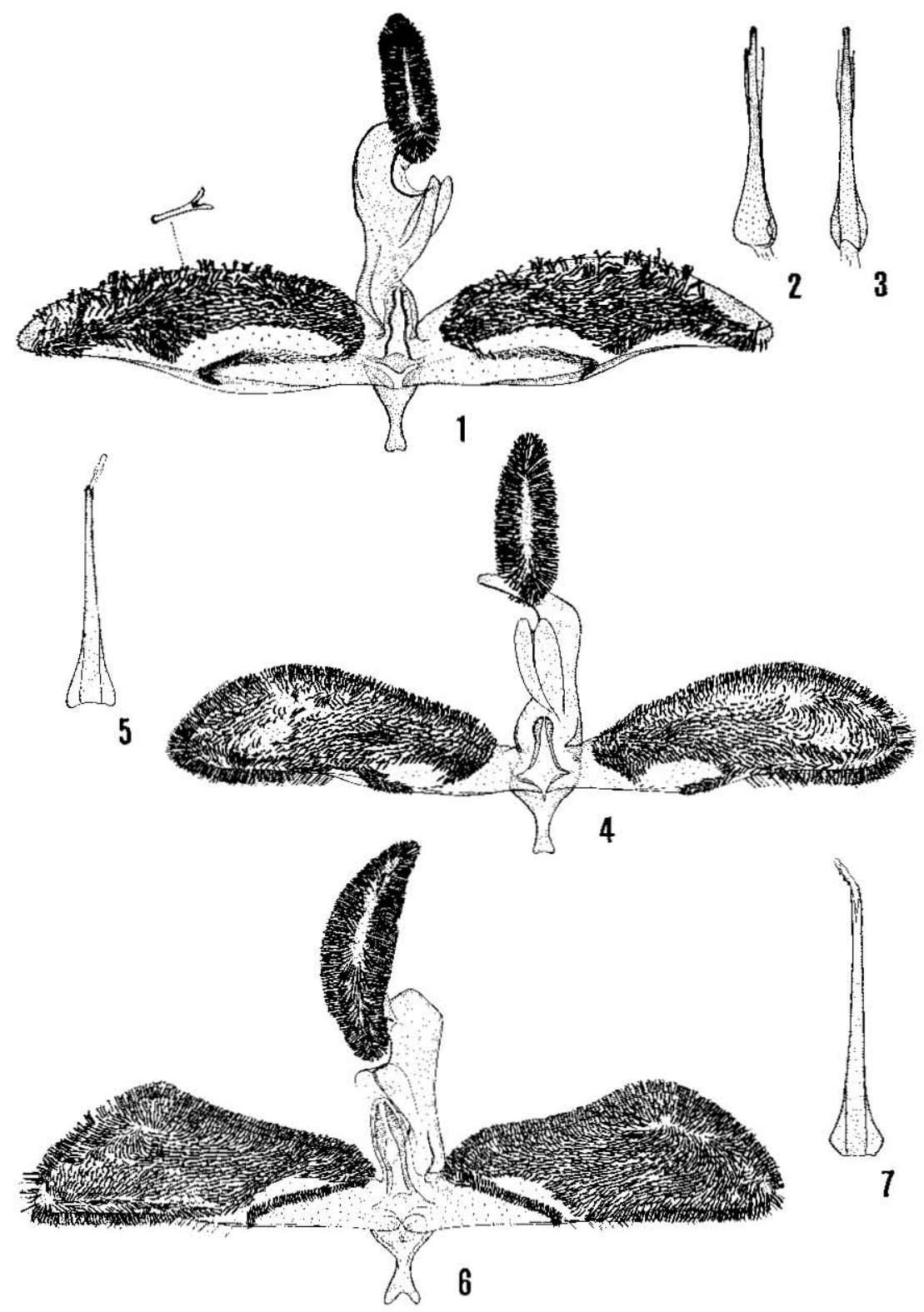

The genera Paranthrene and Conopia from Japan 
Jour. Fac. Agric., Kyushu Univ., Vol. 11

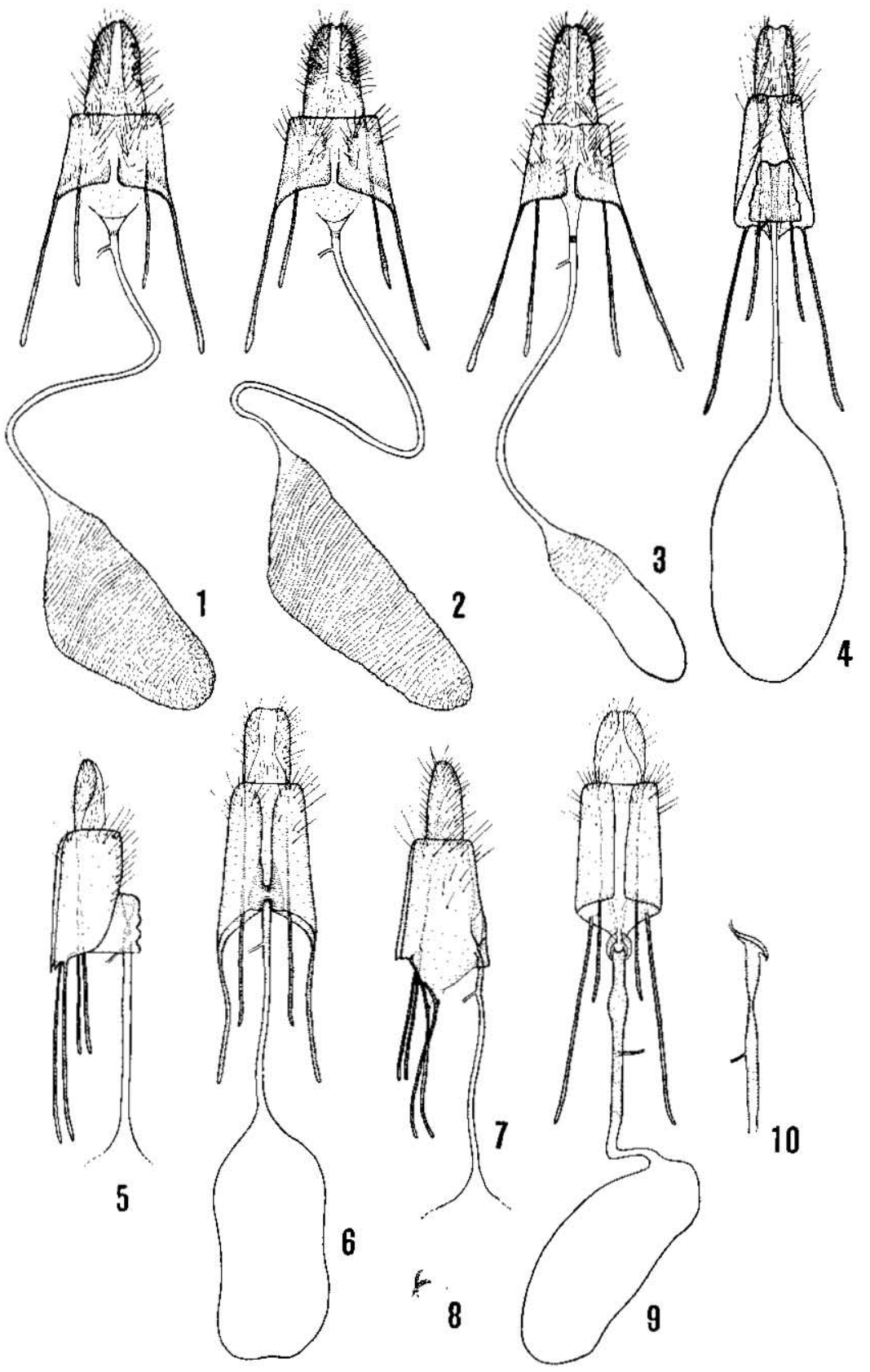

The genera Paranthrene and Conopia from Japan 

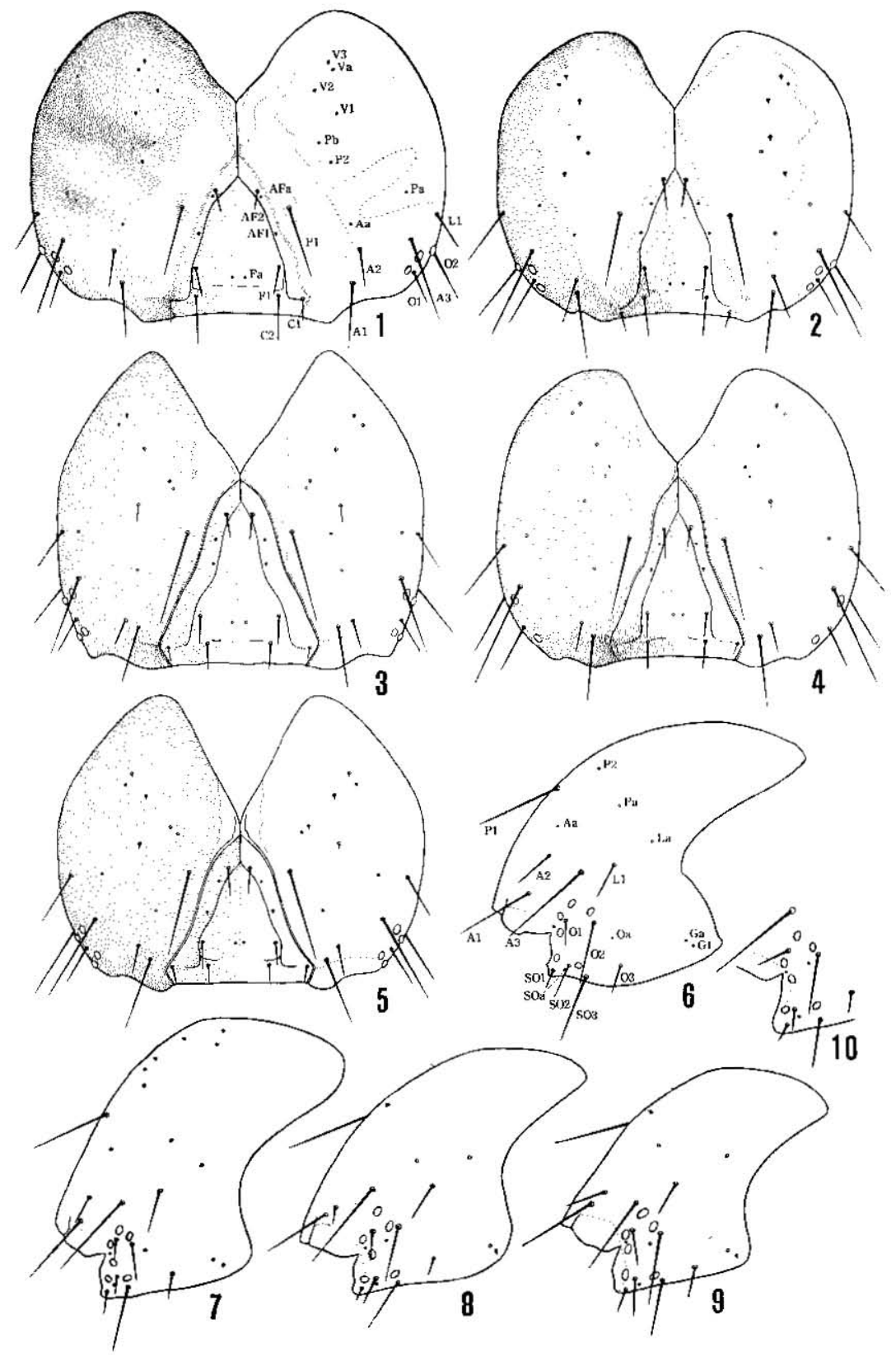

The genera Paranthrene and Conopia from Japan 


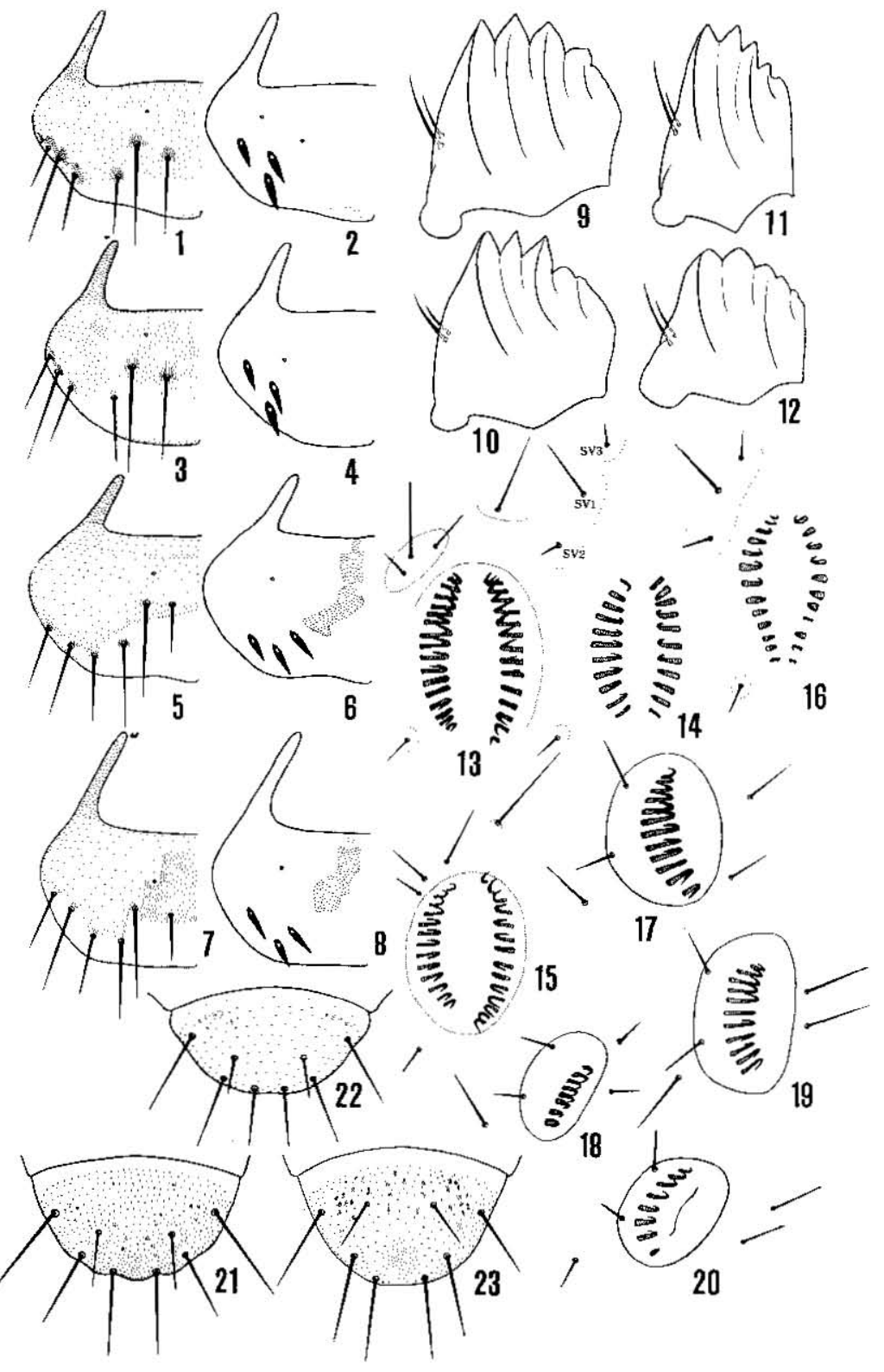

The genera Paranthrene and Conopia from Japan 

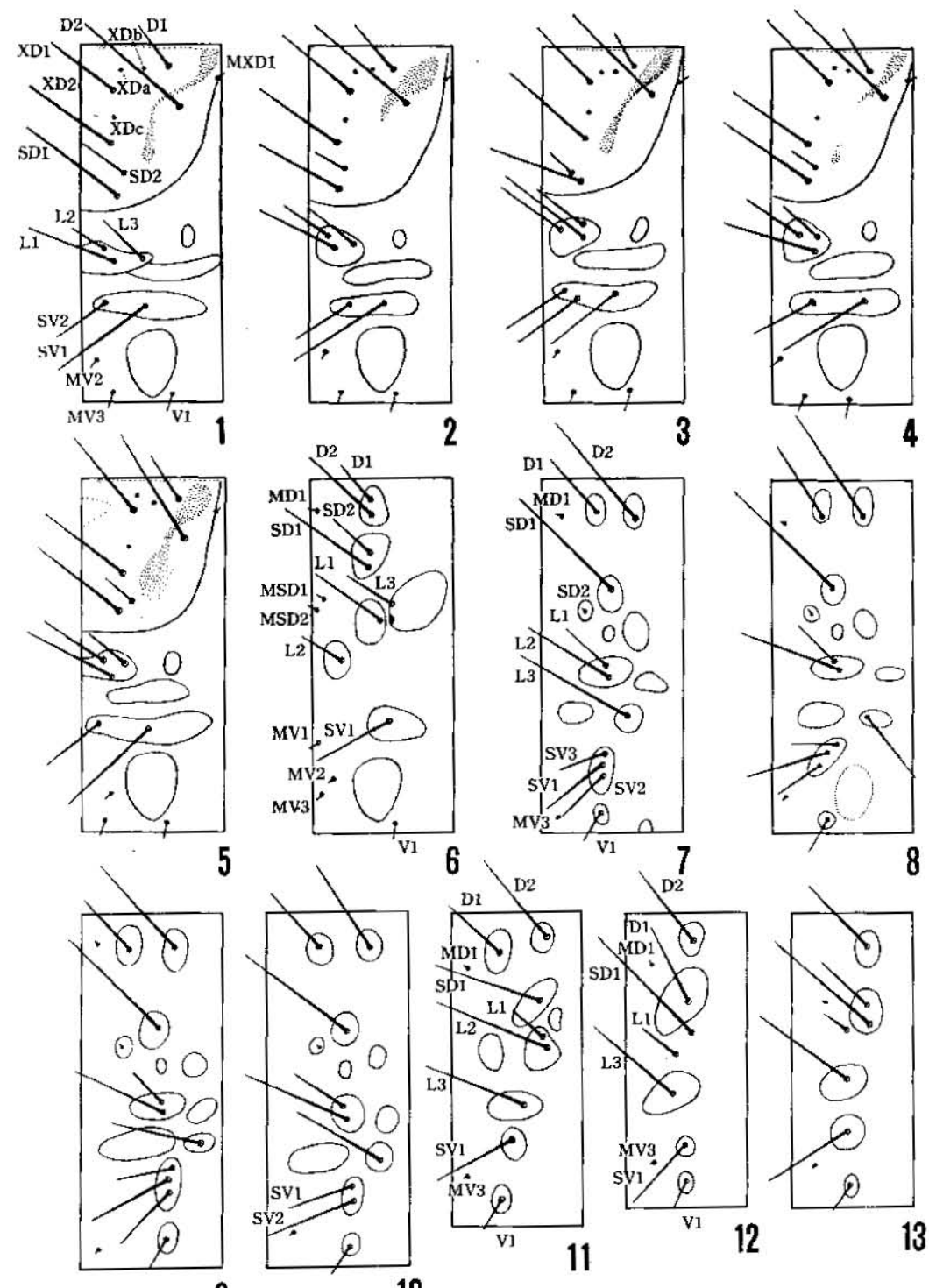

$$
\begin{aligned}
& 00 \\
& 000 \\
& 000 \\
& 0=0 \\
& 0014
\end{aligned}
$$
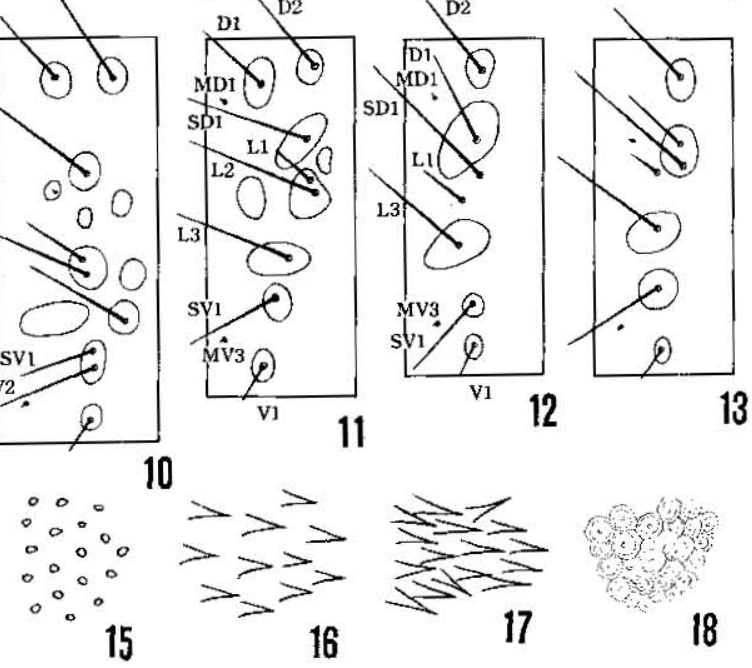

The genera Paranthrene and Conopia from Japan 


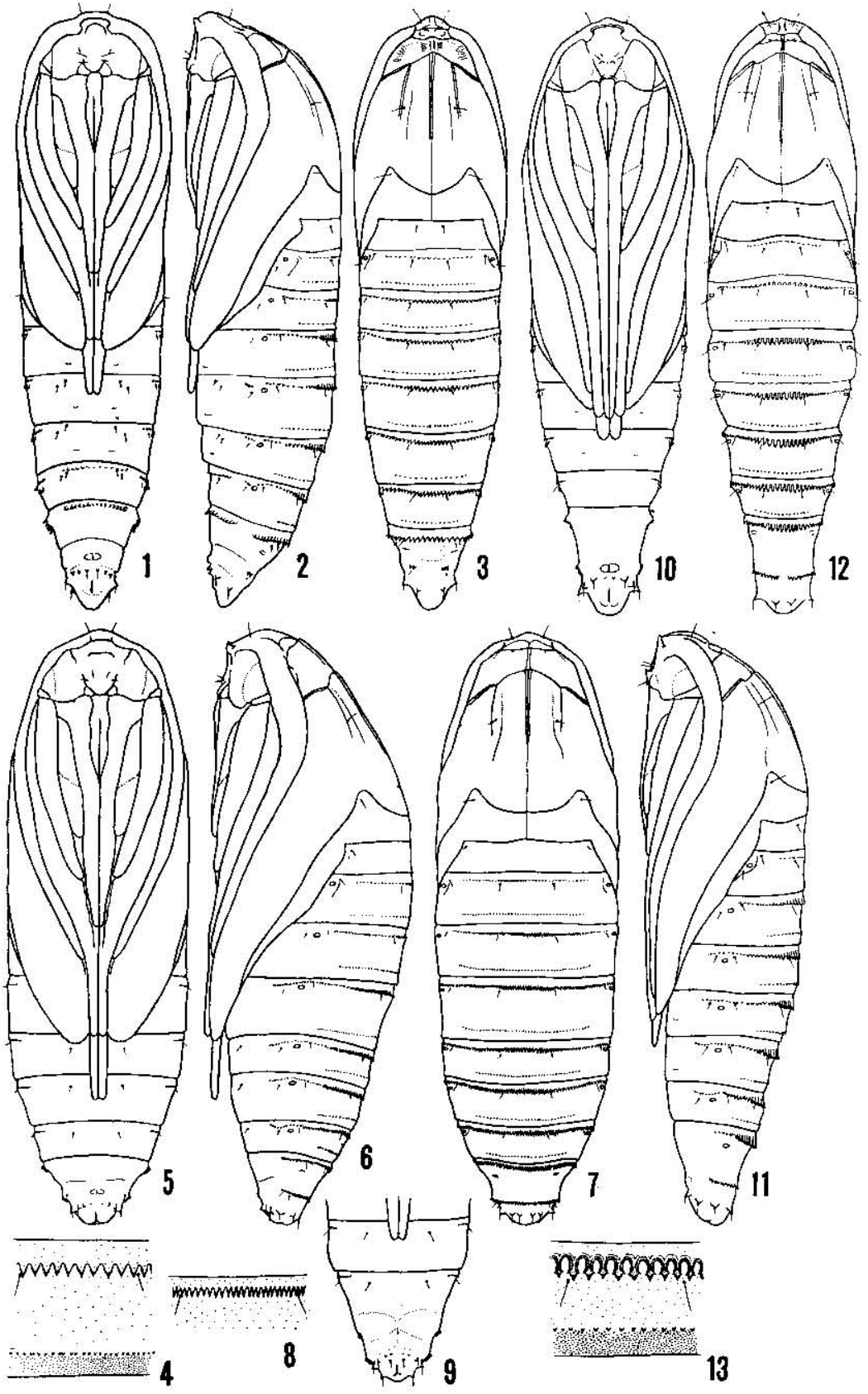

The genera Paranthrene and Conopia from Japan 
Jour. Fac. Agric., Kyushu Univ., Vol. 11
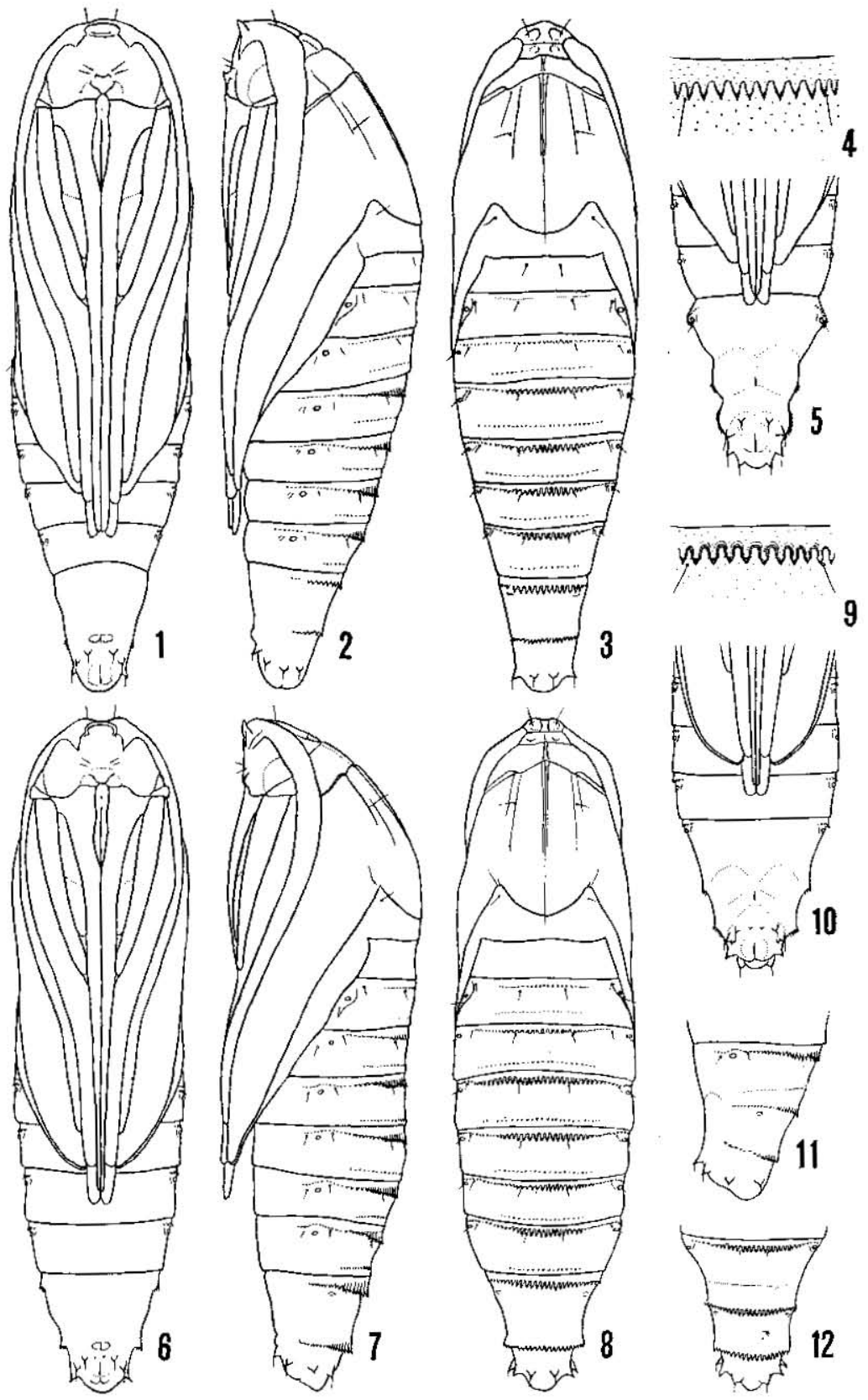

The genera Paranthrene and Conopia from Japan 